\title{
STILL AT ODDS: THE JAPANESE ABDUCTION ISSUE AND NORTH KOREA'S CIRCUMVENTION
}

\author{
Anthony DiFilippo 1 \\ Lincoln University
}

\begin{abstract}
:
During the 1970s and 1980s, North Korea, or as it is known officially, the Democratic People's Republic of Korea (DPRK), abducted a number of Japanese citizens. Especially after the late Kim Jong Il admitted to former Japanese Prime Minister Junichiro Koizumi in September 2002 that agents from the DPRK had kidnapped some Japanese nationals during the Cold War, the abduction issue, which remains unresolved, became highly politicized in Japan. Pyongyang, however, has continued to maintain for some time now that the abduction issue was settled several years ago, while also insisting that Japan must make amends to the DPRK for its past colonization of the Korean Peninsula. For its part, Tokyo has remained adamant about the need to resolve the abduction issue, repeatedly stressing that it is one of the few major problems preventing the normalization of Japan-North Korea relations. Largely because of the strong security relationship between the United States and Japan, which for the past several years has had to contend with the North Korean missile and nuclear weapons issues, this paper also examines Washington's changing position on the abduction issue.
\end{abstract}

Keywords: Japanese abduction issue, North Korean missile and nuclear weapons issues, the history problem, politicization of the abduction issue, six-party talks, the U.S. position on the abduction issue.

\section{Resumen:}

Durante las décadas de 1970 y 1980, Corea del Norte, o tal y como se la conoce oficialmente, la República Democrática Popular de Corea (RDPC), secuestró a una serie de ciudadanos japoneses. Este asunto, hoy por hoy todavía sin resolver, se ha politizado enormemente en Japón, en particular desde que el difunto Kim Jong-Il admitiese al anterior primer ministro japonés, Junichiro Koizumi que efectivamente la RDPC había secuestrado ciudadanos japoneses durante la Guerra Fría. Pyongyang sin embargo lleva desde hace un tiempo manteniendo que el asunto relativo a los secuestros quedó resuelto hace varios años, a la par que insiste en que Japón ha de pedir disculpas a la RDPC por la colonización de la Península de Corea. Por su parte, Tokio se mantiene firme en lo que respecta a la necesidad de resolver el problema de los secuestros, subrayando que es uno de los principales problemas que se oponen a la normalización de las relaciones Japón-Corea del Norte. En gran medida por la fuerte relación de seguridad que liga a Japón con los Estados Unidos, y que en los últimos años se ha tenido que enfrentar al desafío múltiple de los lanzamientos de misiles balísticos y los ensayos nucleares, este artículo también trata la cambiante postura de Washington en relación con el asunto de los secuestros.

Palabras clave: Secuestro de japoneses, problema nuclear de Corea del Norte, problema histórico, politización de los secuestros, Conversaciones a Seis Bandas, postura de los EEUU sobre los secuestros.

Copyright @ ( UNISCI, 2013.

Las opiniones expresadas en estos artículos son propias de sus autores, y no reflejan necesariamente la opinion de UNISCI. The views expressed in these articles are those of the authors, and do not necessarily reflect the views of UNISCI.

\footnotetext{
${ }^{1}$ Anthony DiFilippo is Proffesor at the Department of Sociology and Anthropology of the Lincoln University.

E-mail: difilippo@lincoln.edu.

http://dx.doi.org/10.5209/rev_UNIS.2013.n32.440u
} 


\section{Introduction}

Although suspicions existed in Japan for a number of years, Japanese officials first formally raised the abduction issue in the early 1990s during normalization discussions with the Democratic People's Republic of Korea (DPRK). ${ }^{2}$ Since then, it has remained an enduring and significant thorn plaguing Japan-North Korean relations. For Tokyo, it is one of the three major problems preventing rapprochement with the DPRK, of which the other two are the North Korean missile and nuclear weapons issues. During the 1970s and 1980s agents from the DPRK kidnapped - without authorization, according to the late Kim Jong Il - a number of Japanese nationals. These abductions, which occurred subsequent to the Japanese annexation of the Korean Peninsula from 1910 to 1945 and to the coercion of thousands of Korean women who were used as comfort women or sex slaves for Japan's imperial forces, two unresolved issues from the DPRK's perspective, symbolized the heightened animosity that existed during the Cold War between Pyongyang and Tokyo. Because of this Cold War tension, at least some in North Korea believed that the abductees would be able to train DPRK agents to act and speak Japanese.

As horrific as these abductions were, neither North Korea nor Japan has been an innocent victim in the poor bilateral relationship that has existed between them. For example, Tokyo sees Japan's defeat in the Pacific War as the demarcation line between of the atrocities attendant to its imperialist past and its postwar role as a respectable member of the international community. This perspective has encouraged Tokyo to claim that the abductions by North Korea were acts of international terrorism, while marginalizing the "history problem" as it pertains generally to the Korean Peninsula and specifically to the DPRK.

Since the early 1950s, the United States has maintained a bilateral security relationship with Japan. Referring to the Asia Pacific region, Deputy Secretary of Defense Ashton Carter noted during a recent visit to Japan in July 2012: "And of course Japan is our central and anchoring alliance, and has been for many decades, and so naturally I come here first, to Tokyo." 3 A central concern of and justification for the U.S.-Japan security alliance today, as it was during the Cold War, is North Korea. As will be discussed below, since the Clinton administration, Washington has exhibited shifting positions on the Japanese abduction issue.

\section{Looking Back}

Early on, the abduction issue interfered with Japan-North Korean normalization talks. ${ }^{4}$ Indeed, Japan and the DPRK did not hold normalizations talks between 1992 and 2000. Pyongyang's decision to launch the Rodong-1 missile in May 1993 and especially its firing of the more advanced and longer-range Taepodong-1 in August 1998, which the North named the Kwangmyŏngsŏng- 1 and maintained it was a civilian satellite, worsened the already-poor Japan-DPRK relationship. The latter launch, for sure, put on hold any hopes of Tokyo and Pyongyang having normalization talks. Launched without advance notice, the Taepodong-1 crossed over Japanese territory. Tokyo responded to the launch by immediately cutting off food assistance to the DPRK, announcing its intention to continue with the plan to strengthen Japan's security relationship with Washington, which eventually included joint research with

\footnotetext{
${ }^{2}$ Ministry of Foreign Affairs of Japan (MOFA): Outline and Background of Abduction Cases of Japanese Nationals by North Korea, Tokyo, April 2002, at www.mofa.go.jp/region/asia-paci/n_korea/abduct.html.

${ }^{3}$ U.S. Department of Defense: "Media Roundtable with Deputy Secretary of Defense Carter", Tokyo (21 July 2012), at www.defense.gov/transcripts/transcript.aspx?transcriptid=5082.

${ }^{4}$ Unless otherwise noted, much of this section is drawn from DiFilippo, Anthony (2012): US-Japan-North Korea Security Relations: Irrepressible Interests, London and New York, Routledge, 2012, chapter 4.
} 
the United States on missile defense, and by ending - but only for a short time - assistance to KEDO (Korean Peninsula Energy Development Organization). ${ }^{5}$

Formed as an international consortium (initially the United States, Japan and South Korea) in March 1995, KEDO had its origin in the October 1994 Agreed Framework between Washington and Pyongyang. Ending the first North Korean nuclear crisis of the early 1990s, the Agreed Framework froze the DPRK's plutonium-producing activities at Yongybyon and Taechon. KEDO was mainly created to supply the energy assistance to the DRPK stated in the Agreed Framework in exchange for its nuclear freeze, specifically by providing regular shipments of heavy oil to the DPRK, and to finance the construction of two light-water reactors. Because of the continued worsening of the second North Korean nuclear crisis that emerged in October 2002, the heavy oil shipments stopped in December 2002 and the funding for the reactors, which were never completed, ended in May $2006 .^{6}$

For many years after Tokyo officially raised the abduction issue in the early 1990s, the DPRK emphatically denied that it had kidnapped any Japanese citizens, referring to them only as "missing persons." However, Japanese conservatives, specifically the nationalists, were dogged, and continued to point to the DPRK as being culpable for the kidnappings.

The DPRK's first responded to the abduction charges harshly, eventually insinuating that South Korea's Agency for National Security Planning (ANSP) was somehow involved in this matter. Pyongyang also maintained that the act of kidnapping violated the principals of juche (self-reliance), the DPRK's official ideology. One of the missing persons, Megumi Yokota, who came to symbolize the egregiousness associated with the DPRK's perpetration of abducting Japanese nationals, was only 13 years old when she disappeared in November 1977. Pyongyang's attempt to dissociate the DPRK from the abductions went way beyond what could be considered reasonable, claiming "It is nobody's secret that Mayumi [sic] was an agent of the "ANSP'", 7

In early June 1998, the Korean Central News agency, the official news outlet of the government and the Workers' Party of the DPRK, published the findings of the investigation asked for by Japan with respect to the missing persons. The spokesperson for the North Korean Red Cross Society noted an investigation concerning the whereabouts of Japanese citizens (at the time 10 had been identified by Japan's National Police Agency) in the DPRK was meticulously performed for five months earlier in the year and that it had been supervised by government organizations. The DPRK Red Cross Society indicated: "Regrettably, however, none of the ten sought by Japan was found out. The results of the search finally proved that the persons wanted by Japan do not exist in the DPRK territory and that they never entered nor temporarily stayed here." " Just a few days later, the North Korean Foreign Ministry reiterated the findings of the Red Cross Society, noting also that, although Japan had withdrawn the use of the words "suspected kidnapping" by Pyongyang and asked instead to locate the missing persons, the thorough investigation showed that the DPRK was not in any way involved with their disappearance. 9

\footnotetext{
5 DiFilippo, Anthony (2012): The Challenges of the U.S.-Japan Military Arrangement: Competing Security Transitions in a Changing International Environment, Armonk, NY and London, M.E. Sharpe, pp. 45-46; DiFilippo, Anthony (2006): Japan's Nuclear Disarmament Policy and the U.S. Security Umbrella, New York: Palgrave Macmillan, p. 24.

${ }^{6}$ See KEDO, at www.kedo.org/Index.asp.

7 "Japan's Papers used by S. Korea in Anti-DPK Campaign”, Korean Central News Agency, 11 February 1997.

8 "Results of Search for Missing Published", Korean Central News Agency, 5 June 1998.

9 “Japanese Authorities' Abuses of the DPRK Denounced", Korean Central News Agency, 11 June 1998.
} 
Pushed by Japanese nationalists in particular, the abduction issue would not go away. By early 2000, there was a ray of hope that Japan-DPRK relations could realize some improvement. Because in December 1999 Pyongyang had stated that it was willing to "continue the investigation as the case of missing persons," Tokyo decided in March 2000, though not without some resistance from the right, to resume the food aid to the DPRK that it had cut off because of the launching of the mid-range Taepodong-1 in August 1998. Japan and the DPRK held normalization talks in April, August and October of 2000. During the talks in August, Pyongyang said that the DPRK's Red Cross, working in cooperation with the government, was performing a "thorough investigation of the missing persons." For Tokyo, the abduction issue was a critical obstacle that impeded the progress of rapprochement, while Pyongyang remained largely focused on issues pertaining to the history problem stemming from the Japanese colonization of the Korean Peninsula. In short, Japan-DPRK normalization talks held in 2000 did not accomplish much. In December 2001, the North Korean Red Cross Society announced, to Tokyo's chagrin, that it was completely suspending the investigation of the missing persons. ${ }^{10}$ The statement issued by the North Korean Red Cross also maintained that "riffraffs in Japan are these days making much fuss about the issue of 'suspected kidnapping', a fiction, at the connivance and instigation of the government authorities to seriously get on the DPRK's nerves." 11

By the late 1990s, the abduction issue was getting a good bit of public attention, to some extent because of the media. During this time, two major support organizations were formed, the Association of the Families of Victims Kidnapped by North Korea (AFVKN, in 1997) and the National Association for the Rescue of Japanese Kidnapped by North Korea (NARKN, in 1998). Both of these organizations worked (as they still do today) to increase public awareness and government action. Although it is difficult to pinpoint the exact date of when the abduction issue became politicized, certainly some evidence of this existed in 2000 . Just a few weeks before the Japan-DPRK normalization talks were held in October 2000, Prime Minister Yoshiro Mori of the Liberal Democratic Party (LDP) told family members of the abductees: "It would be unthinkable for the government to normalize relations while ignoring the alleged abductions."

Indeed, by October 2000 it would have been political suicide for any Japanese politician to ignore the abduction issue. Survey results from the government of Japan's Cabinet Office conducted in October 2000 showed that over 68 percent of the respondents expressed concern about the abduction issue. In contrast, just slightly above 52 percent of the survey respondents at this time said they were concerned about the DPRK missile problem and about 39 percent worried about the North Korean nuclear issue. ${ }^{12}$

In April 2001, the LDP's Junichiro Koizumi became prime minister of Japan. Koizumi's politics were generally conservative. Although Koizumi was not a nationalist, he was not averse to the influence of nationalists. Prior to becoming prime minister, Koizumi was far from fully knowledgeable about details associated with normalizing Japan-DPRK

\footnotetext{
${ }^{10}$ MOFA: "Outline and Background of Abduction Cases of Japanese Nationals by North Korea", Tokyo (April 2002); Manyin, Mark: "North Korea-Japan Relations: The Normalization Talks and the Compensation/Reparations Issue", The Library of Congress, Congressional Research Service, Washington, D.C., (13 June 2001), at http://assets.opencrs.com/rpts/RS20526 20010613.pdf.

11 "Report of DPRK Red Cross Society”, Korean Central News Agency, 17 December 2001.

12 "Abduction Politics: North Korea, Japan and the Politics of Fear and Outrage", 21 January 2008, at http://ishingen.wordpress.com/tag/new-conservatives/.
} 
relations. But he was not opposed to it. And so, when Pyongyang began pursuing rapprochement after he became prime minister, Koizumi responded favorably. ${ }^{13}$

However, the Koizumi government faced a major obstacle: its security alliance partner, the United States. The end of the Clinton administration's time in Washington saw some thawing in the U.S.-DPRK relations, capped by the unprecedented trip to Pyongyang in October 2000 by Secretary of State Madeleine Albright. Her trip to Pyongyang came on the heels of a joint statement on international terrorism and a joint communiqué with the DPRK, both issued earlier in the month. In the joint statement Washington indicated that "as the DPRK satisfactorily addresses the requirements of U.S. law, the U.S. will work in cooperation with the DPRK with the aim of removing the DPRK from the list of state sponsors of terrorism." Besides announcing Albright's trip to the DPRK and the possibility of one by President Clinton (that never occurred while he was in office), the joint communiqué stressed that Washington and Pyongyang would work to build trust and confidence. The North also promised in this document "that it will not launch long-range missiles of any kind while talks on the missile issue continue." 14 Regarding the Japanese abduction issue, the Clinton administration had informed Tokyo before the end of 2000 that the (alleged) kidnappings by the DPRK would not stop Washington from taking North Korea off of the U.S. list of countries sponsoring terrorism, which it initially appeared on in the State Department's 1983 report, ${ }^{15}$ since they were unrelated matters. ${ }^{16}$ However, it did not take too long after George W. Bush became president for there to be discernible changes in U.S. policy toward the DPRK. And this new policy required compliance from Tokyo, the junior partner in the U.S.Japan security alliance.

The Bush administration appears to have believed even more strongly than its predecessor that the collapse of the DPRK was likely to occur. Moreover, it was not a very well kept secret that several key officials in the Bush administration did not accept its predecessor's policy on North Korea and were especially disdainful of the 1994 Agreed Framework. Conservative and neoconservative elements with the Bush administration saw no need for the continuation of engagement with North Korea; rather, they pushed hard for adopting a hard-line policy.

At the end of August 2002, the Koizumi government announced that in September the prime minister would make a historic trip to Pyongyang. While publicly President Bush suggested that he supported Koizumi's trip, privately he and his administration had an entirely different position. Bush informed Koizumi that the United States could not support the normalization of Japan-DPRK relations until the North abandoned its efforts to develop nuclear weapons. The Bush administration told Tokyo that it did not want Japan to offer food

13 DiFilippo, Anthony: "Kojireta kankei no nichicho kokko seijohka (The Troubled Relationship: What Normalized Relations Would do for Japan and North Korea)", in Kitachosen o Meguru Hokutoh Ajia no Kokusai Kankei to Nihon (Japan and Northeast Asian International Relations Involving North Korea), Hirama, Yoichi and Sugita, Yone (2003) (ed.): Tokyo, Akashi Shoten, pp. 66-84; Funabashi, Yoichi (2007): The Peninsula Question: A Chronicle of the Second North Korean Nuclear Crisis, Washington, D.C., Brookings Institution Press, pp. 64-66.

${ }^{14}$ U.S. Department of State: “Joint U.S.-DPRK Statement on International Terrorism”, Washington, DC. (6 October 2000), at http://statelists.state.gov/scripts/wa.exe?A2=ind0010b\&L=uskorea-kr\&F=\&S=\&P=74; U.S. Department of State: "U.S.-DPRK Joint Communiqué", Washington, DC. (12 October 2000), at http://usinfo.org/wf-archive/2000/001012/epf407.htm.

${ }_{15}$ DiFilippo, Anthony: "North Korea as a State Sponsor of Terrorism: Views from Tokyo and Pyongyang," International Journal of Korean Unification Studies", vol. 17, no. 1 (2008), p. 2.

16 Pritchard, Charles (2007): Failed Diplomacy: The Tragic Story of How North Korea Got the Bomb, Washington, DC., The Brookings Institution, p. 86. 
aid to North Korean as a carrot to move the abduction issue forward, preferring instead that this assistance come from the United Nations. The Bush administration also told the Koizumi government at the end of August that it had information that North Korea had been concealing a uranium-enrichment program to develop nuclear weapons. ${ }^{17}$ The 1994 Agreed Framework between the United States and the DPRK prohibited North Korea from having such a program in that it referenced the Joint Declaration on the Denuclearization of the Korean Peninsula, which was signed by Seoul and Pyongyang in early 1992 and which expressly stated that the two Koreas "shall not possess nuclear reprocessing and uranium enrichment facilities."

Koizumi visited Pyongyang for one day on September 17, 2002. Meeting with North Korean leader Kim Jong Il, the two signed the Pyongyang Declaration, which established a foundation for rapprochement. Among other things the Pyongyang Declaration stated that Japan and the DPRK would work to resolve missile and nuclear issues, that the North would continue to suspend missile launches in 2003 and beyond, and that they would work to normalize bilateral relations, with talks to resume in October. Moreover, the Pyongyang Declaration noted that Japan had caused much suffering and serious problems when it colonized Korea and significantly, because Kim admitted to Koizumi that North Korean agents had previously abducted Japanese nationals, the document stated that the DPRK promised "that these regrettable incidents, that took place under the abnormal bilateral relationship, would never happen in the future." 19

During their summit in September 2002, Kim told Koizumi that the abductions were not authorized by the DPRK but that the agents responsible for the kidnappings acted on their own. According to Tokyo, at this summit the DPRK promised to punish those responsible for the abductions. However, Tokyo maintains that although the DPRK provided the court records of the agents' hearing, parts have been deleted and there are few specific references to the abductions in their trial, which took place in 1998 and $1999 .{ }^{20}$ Pyongyang later maintained that the two agents responsible for the kidnappings - Jang Bong Rim and Kim Sung Chol - had been executed. ${ }^{21}$

In April 2002, several months before the Koizumi-Kim summit, the Japanese Ministry of Foreign Affairs identified 11 nationals who it believed had been abducted by North Korea. ${ }^{22}$ However, Kim told Koizumi at their September summit that 13 Japanese nationals had been abducted by DPRK agents. Said Kim at the time, only five of the abductees were still living; the other eight had died and that the DPRK could not verify that another person, who Tokyo had identified as a victim, was ever in the DRPK. ${ }^{23}$ On the same day of the summit the North Korean Foreign Ministry issued a statement stipulating that the DPRK

17 DiFilippo, Anthony: "Security Trials, Nuclear Tribulations, and Rapprochement in Japan North-Korean Relations", The Journal of Pacific Asia, vol. 11 (2004), pp. 13-14.

18 "Joint Declaration on the Denuclearization of the Korean Peninsula", 19 February 1992, at

www.fas.org/news/dprk/1992/920219-D4129.htm.
19 MOFA: "Japan-DPRK Pyongyang Declaration", $\quad$ Pyongyang $\quad(17 \quad$ September $\quad 2002), \quad$ at www.mofa.go.jp/region/asia-paci/n korea/pmv0209/pyongyang.html.

${ }^{20}$ Secretariat of the Headquarters for the Abduction Issue: "Abductions of Japanese Citizens by North Korea", Tokyo (May 2011), at www.rachi.go.jp/en/ratimondai/syousai.html\#rm02; Government of Japan, Headquarters for the Abduction Issue: "For the Return of All of the Abductees", Tokyo (August 2008).

${ }^{21}$ Author interview with research specialist on Japan in the DPRK Ministry of Foreign Affairs, Pyongyang, 8 January 2009.

${ }^{22}$ MOFA: "Outline and Background of Abduction Cases of Japanese Nationals by North Korea" (April 2002).

${ }^{23}$ MOFA: “Abductions of Japanese Citizens by North Korea”, Tokyo (2012). 
would "take necessary steps to let them return home or visit their hometowns if they wish.",24 Less than two weeks after the Koizumi-Kim summit, Tokyo sent a team to the DPRK to investigate the fate of the abductees whose cases remained unexplained. Tokyo maintains that Pyongyang was not too cooperative and that the remains it stated might belong to Kaoru Matsuki, one of the abductees, were not his. At the DPRK-Japan normalization talks held at the end of October 2002, Tokyo raised 150 questions it said were "inconsistencies" associated with the abduction issue. ${ }^{25}$

In mid October 2002, Pyongyang allowed the 5 surviving abductees it had identified in September to travel to Japan, with the understanding that they would return to the DPRK. However, spurred by Japanese conservatives and abductee support organizations, such as NARKN and AFVKN, the abduction issue had taken on a political life of its own. Toward the end of November 2002 the announcement came that the five abductees, despite what was believed to be reservations and even resistance on their part, would not be returning to North Korea. $^{26}$

Pressed by the right, the public acceptance of the unresolved abduction issue showed up clearly in government surveys. Between October 2002 and October 2003, concern about the abduction issue among Japanese survey respondents increased from 83.4 percent to 90.1 percent. These data indicated a noticeably higher concern than that for the DPRK missile and nuclear issues, even though both had increased sharply since 2000. That President George W. Bush declared in his state of the union address in January 2002 that North Korea was part of an "axis of evil" could have only helped to raise security concerns in Japan. The nuclear issue had become even more of a concern amongst the Japanese public after U.S. Assistant Secretary of State for East Asian and Pacific Affairs James Kelly traveled to Pyongyang in early October 2002 and told officials there that Washington had information that the DPRK had secretly been maintaining a uranium-enrichment program to develop nuclear weapons. Eventually, Pyongyang adamantly and continually maintained that it had no such program. This, however, did not convince Washington, Tokyo or Seoul, especially since U.S. officials had previously maintained that the DPRK had stockpiled plutonium and possibly had enough to build one or two nuclear weapons. Thus, in Japan, concern about the North Korean nuclear issue grew from 39.3 percent in 2000, to 49.2 percent in 2002, to 66.3 percent by October $2003 .^{27}$

Things then began to spin out of control, with both Washington and Pyongyang accusing each other of violating the Agreed Framework. So, for example, while Washington claimed that North Korea violated the Agreed Framework by maintaining a clandestine uranium-enrichment program, Pyongyang stressed that the Bush administration's threat to use nuclear weapons against the DPRK in its 2002 Nuclear Posture Review directly contravened the bilateral accord. ${ }^{28}$ After KEDO stopped shipments of heavy oil to North Korea at the end

\footnotetext{
24 "DPRK Foreign Ministry Spokesman on Issue of Missing Japanese," Korean Central News Agency, 17 September 2002.

25 "Abductions of Japanese Citizens by North Korea", op. cit..

${ }^{26}$ Johnston, Eric: "The North Korea Abduction Issue and its Effect on Japanese Politics," Center for the Pacific Rim (University of San Francisco), Japan Policy Research Institute (JPRI), Working Paper JPRI no. 101 (June 2004).

27 "Abduction Politics...", op. cit.

${ }^{28}$ The 1994 Agreed Framework between Washington and Pyongyang states: "The U.S. will provide formal assurances to the DPRK, against the threat or use of nuclear weapons by the U.S.". The 2002 Nuclear Posture Review indicates that North Korea is one of several countries in which the United States "could be involved [with] in immediate, potential, or unexpected [nuclear] contingencies." See Nuclear Posture Review
} 
of 2002, Pyongyang threw out inspectors from the International Atomic Energy Agency, restarted its plutonium reprocessing at Yongbyon that had been frozen by the Agreed Framework and withdrew from the Nuclear Nonproliferation Treaty as a nonnuclear weapons state in April 2003.

The emergent North Korean nuclear crisis helped Japanese nationalists cement their repeated claim that the kidnapping of Japanese citizens were acts of terrorism - a position that in fact Koizumi first conveyed to President Bush in February 2002 well before the onset of the DPRK nuclear problem. As noted above, while the Clinton administration had drawn a line in the sand telling Tokyo that the removal of the DPRK from the U.S. list of states sponsoring terrorism was a separate matter from the kidnapping of Japanese nationals, the administration of George W. Bush fully embraced the abduction issue. In 2003, Tokyo began trying to convince the Bush administration to include the abduction issue as another reason for the DPRK being on the U.S. State Department's list of countries that sponsor terrorism. This did not require much arm twisting on Tokyo's part for two reasons. First, Bush and Koizumi had established a reasonably good personal relationship. Secondly, the president and several hard-line officials in his administration had become drawn to the abduction issue, particularly since it comported well with their interests in human rights violations that they believed were widespread in the DPRK. Tokyo's appeals to the Bush administration for the specification of the abduction issue as a reason for the DPRK remaining on the list of states sponsoring terrorism paid off. In April 2004, Washington informed Tokyo that the abduction issue would be included as a reason for the DPRK being listed on the State Department's then forthcoming annual report on global terrorism. Tokyo also tried hard to have the abduction issue included in the six-party talks between the United States, North and South Korea, China, Japan and Russia that began in August 2003 to resolve the North Korean nuclear issue. There were, however, strong objections from all of the other parties, with the exception of the United States. Still, President Bush demonstrated a particularly strong and enduring interest in the abduction issue.

Prime Minister Koizumi made a second trip to Pyongyang in late May 2004 and again met with Kim Jong Il. In addition to the abduction problem, the two leaders discussed the North Korean nuclear and missile issues and some other matters of concern to Japan and the DPRK. After the conclusion of the one-day summit, Koizumi returned to Japan with some family members of the abductees, with others arriving in Japan in July. The North also said at this summit that it would reopen and fully investigate the abduction issue. Japan and the DPRK held working-level talks in August, September and November of 2004 but to no avail. In December 2004, Tokyo informed Pyongyang that information provided by the DPRK about the abductees was unsatisfactory and did not represent a complete investigation of the matter. Moreover, Tokyo maintained that the remains of Megumi Yokota that the DPRK had provided were not hers. ${ }^{29}$ The controversy surrounding the examination of the remains of Megumi Yokota provided Japanese nationalists the opportunity to promote even more so than in the past the unswerving requirement of resolving the abduction issue.

At six-party talks held in June 2004, Tokyo formally linked the normalization of relations with the DPRK to the resolution of the abduction, nuclear and missile issues. ${ }^{30} \mathrm{In}$

(Reconstructed), submitted to Congress on 31 December 2001, Washington (8 January 2002), at Www.fas.org/blog/ssp/united_states/NPR201re.pdfon.

29 "Abductions of Japanese Citizens by North Korea", op. cit.

${ }^{30}$ MOFA: "Third Round of the Six-party Talks Concerning North Korean Nuclear Issue", Tokyo (June 2004), at www.mofa.go.jp/region/asia-paci/n_korea/6party/talk0406.html; Embassy of Japan: "Japan Pursued 
February 2005, Pyongyang announced that the DPRK had "manufactured nukes for selfdefence," in early July 2006 it launched several missiles, including a long-range Taepodong-2 and on October 9, 2006 North Korea conducted its first underground nuclear test, ${ }^{31}$ as it often said to counter and deter what it saw as a hostile, and potentially military aggressive, U.S. policy pursed by the Bush administration. Even though prospects for rapprochement between Japan and the DPRK began to wither steadily after normalization talks failed in October 2002, Pyongyang's decision to conduct a nuclear test meant that the normalization of relations between Japan and the DPRK had no chance of being resolved anytime in the immediate future. Tokyo was fully cognizant of what Washington expected, which was that the denuclearization of the DPRK, in particular, had to be satisfactorily dealt with before there could be improvement in Japan-North Korean relations.

However, there was also the matter of a change in Japanese leadership. In late September 2006, the nationalist Shinzō Abe became prime minister of Japan for a year. This not only created an additional political charge to the abduction issue, which soared in the Cabinet Office's annual survey to 88.7 percent by 2007 - its highest point since 2003 - as the problem of most concern to Japanese respondents about North Korea, but to the nuclear and missile issues as well. Although survey data from the Cabinet Office indicated that concern about the abduction issue remained very high in Japan between 2004 and 2007, averaging nearly 88 percent during this period, the Japanese public clearly began to shift its attention to the North Korean nuclear issue. Concern about the nuclear issue increased steadily from 56.6 percent in 2004 , to 63.9 percent in 2005 , to 79.5 percent in 2006 , declining only modestly to 75.1 percent in 2007. Since the 2006 Cabinet Office survey was conducted from October 617, i.e., the vast majority of it took place in the aftermath of the DPRK nuclear test, it is not surprising that concern about the North Korean missile issue also spiked in that year, rising from 52.2 percent in 2005 to 71.5 percent in $2006 .^{32}$

Abe's fervent commitment to the abduction issue became apparent very quickly. Just three days after taking office as prime minister, Abe announced his plan to establish the Headquarters for the Abduction Issue within the Japanese government. At this time, he met with members of AFVKN. In October, serving as chair and with all members of his cabinet in attendance, Abe assembled the first meeting of the Headquarters for the Abduction Issue.

Because of Pyongyang's decisions to launch missiles in July 2006 and to conduct a nuclear test in October, the UN Security Council passed two resolutions sanctioning the DPRK. But Tokyo also independently sanctioned the DPRK. Immediately after the July missile tests, Tokyo banned the North Korean vessel Mangyongbong-92 from entering Japanese ports for six months - a sanction that still exists today. The Mangyongbong-92 had regularly entered the Japanese port at Niigata to transport Koreans living in Japan who view themselves as overseas nationals of the DPRK - zainichi chōsenjin - to the their adopted homeland. Having had its political influence grow progressively, AFVKN declared that

\footnotetext{
Dismantlement of North Korea's Nuclear Program's in the Third Round of the Six-party Talks", Washington, D.C. (29 June 2004), at www.us.emb-japan.go.jp/english/html/pressreleases/2004/040629.htm.

31 "DPRK FM on Its Stand to Suspend Its Participation in Six-party Talks for Indefinite Period", Korean Central News Agency, 10 February 2005; "DPRK Successfully Conducts Underground Nuclear Test”, Korean Central News Agency, 9 October 2006.

32 “Abduction Politics...", op. cit.; The Maureen and Mike Mansfield Foundation: "Public Opinion Survey on Diplomacy by the Cabinet Office of Japan (Abridged)", New York (2011), at

http://mansfieldfdn.org/program/research-education-and-communication/asian-opinion-polldatabase/listofpolls/2006-polls/public-opinion-survey-on-diplomacy-by-the-cabinet-office-of-japan-abridged-06$\underline{17 /}$.
} 
Tokyo should maintain the ban on the Mangyongbong-92 until there is a resolution to the abduction issue. In September 2006, just before Koizumi left office, the prime minister's cabinet imposed financial restrictions on a number of companies and one individual believed to have been associated with the DPRK's military programs, effectively preventing them from doing business with Japanese establishments. As survey data indicated, the Japanese public fully supported Tokyo's imposition of these sanctions on North Korea, moves that Pyongyang saw as simply towing the line of the Bush administration that was bent on maintaining a hardline DPRK policy.

Washington and Tokyo responded very quickly to the DPRK's first nuclear test. Urging the UN Security Council to react toughly to the North's nuclear test, Prime Minister Abe and President Bush agreed during a telephone conversation to take "decisive action" against the DPRK. Although the UN Security Council unanimously passed a resolution that imposed additional sanctions on the DPRK just a few days after it conducted its nuclear test, Washington and Tokyo took the lead in getting the resolution approved so expeditiously.

For its part, Pyongyang was not at all pleased with the UN Security Council's resolution, calling it "a declaration of war against the DPRK." Pyongyang further maintained that its nuclear deterrent served to counter U.S. nuclear weapons in Northeast Asia and, for this reason, helped to stabilize the region. ${ }^{33}$ For Pyongyang, the DPRK's nuclear deterrent had become integral to songun (military-first), the policy that had surfaced in the mid 1990s under Kim Jong Il. Pyongyang's was also angered by the Abe government's quick decision to impose additional sanctions, which apart from the North's nuclear test, partially resulted, according to the Japanese Chief Cabinet Secretary, because of its lackluster treatment of the abduction issue. That Pyongyang viewed Tokyo as moving Japan steadily on the path toward remilitarization did not help improve bilateral ties with the DPRK - nor did the Abe government's announcement on the final day of the six-party talks held in December 2006 that Japan would launch its fourth spy satellite in early 2007.

Abe pushed hard to increase both the domestic and international awareness of the abduction issue, including additional airtime on NHK (Japan Broadcasting Corporation - the public broadcasting organization) specifically focused on the kidnappings. In February 2007 during Abe's tenure as Japan's top politician, Noel Paul Stookey, who had then been part of the American folk group Peter, Paul and Mary, performed his Song for Megumi at the prime minister's residence for Mr. and Mrs. Yokota - Abe sat next to Megumi's father - and a small number of other guests. ${ }^{34}$ When the moderate Yasuo Fukuda took over as prime minister in late September 2007, he continued to maintain the sanctions imposed on North Korea by Koizumi and Abe governments.

\subsection{A Seismic Shift in U.S. Policy: Jettisoning the Abduction Issue}

In late 2006, the Bush administration reasoned that, the limited success of the six-party-talks notwithstanding, its sustained hard-line policy toward the DPRK had not worked. The most telling indicator of this was that the DPRK had detonated a nuclear weapon. By early 2007, it was evident that the Bush administration had adopted a relatively more conciliatory North Korean policy. How this came about was the confluence of several factors, which presented a serious challenge to Bush's legacy. Bush was facing noticeably high disapproval ratings. Moreover, the Democrats won control of both the House and Senate in the midterm elections

\footnotetext{
33 "DPRK Foreign Ministry Spokesman Totally Refutes UNSC 'Resolution”, Korean Central News Agency, 17 October 2006.

${ }^{34}$ See, Japanese Government Internet TV, at http://nettv.gov-online.go.jp/eng/prg/prg1008.html.
} 
held in November 2006 and the U.S. public was becoming increasingly uncomfortable with the war in Iraq.

But other issues also contributed to the change in the Bush administration's North Korean policy. It had scored no foreign policy wins with the three countries that Bush had identified as being part of his "axis of evil." Determined to stay in Iraq until democracy prevailed there, and viewing Iran as the biggest state sponsor of terrorism, North Korea became the Bush administration's choice for the possible realization of immediate success. What is more, by late 2006, a number of the inflexible hardliners and neoconservative who had influenced policy earlier in the Bush administration had left their positions.

Rebuked earlier by the Bush administration as ineffective largely because they ignored the security concerns of South Korea, Japan, Russia and China, U.S. Assistant Secretary of State for East Asian and Pacific Affairs Christopher Hill had two bilateral meetings in November 2006 and January 2007 with DPRK official Kim Kye-gwan in Berlin. At these meetings Hill and Kim evidently came to an understanding that if Pyongyang fulfilled specific requirements the United States would remove the DPRK from the State Department's list of states sponsoring terrorism and end the restrictions of the Trading with the Enemy Act as they applied to North Korea. Both of these issues later appeared in the agreement that came out of the six-party talks held in Beijing in February 2007.

These developments were very troubling to the Japanese and particularly to the hawkish Abe administration. Of most concern to the Abe government - a concern shared by American hardliners and neoconservatives - was the proposed removal of the DPRK from the U.S. list of states sponsoring terrorism, provided that it meet specific obligations that would lead to denuclearization. Recall that Tokyo had previously pushed hard to have the abduction issue specifically stated in the U.S. report on global terrorism as a reason for the DPRK being identified as a state sponsor of terrorism. Now, the Bush administration's new and relatively conciliatory DPRK policy, Tokyo reasoned, planned to abandon Japan, the chief ally of the United States in East Asia, so that it could possibly realize the denuclearization of North Korea.

In accordance with the "action for action" criterion previously laid out in the six-party talks, the joint statement from the February 2007 meetings stated that in exchange for taking specific steps toward denuclearization, including shutting down and in time disabling nuclear activities at its Yongbyon facilities, Pyongyang would receive substantial energy, humanitarian and economic assistance from the other parties. Determined not to provide aid to the DPRK until after progress - as defined by Tokyo - had been made on the abduction issue, and not at all pleased with the Bush administration's proposal to delist the DPRK from the U.S. terrorism list, the Abe government announced that it would not contribute to the assistance package. Quoting the passage contained in the joint statement of the six-party talks held in February 2007, the U.S. State Department's 2006 report on global terrorism (published in April 2007) avowed that Washington would "begin the process of removing the designation of the DPRK as a state-sponsor of terrorism.," 35

Displeased with the plan, Tokyo, as well as family members of the abductees, tried to convince the Bush administration to keep the DPRK on the U.S. terrorism list until after the abduction issue had been settled. At the core of Japanese hard-line position was the contention

\footnotetext{
${ }^{35}$ U.S. Department of State: Country Reports on Terrorism, chapter 3, Washington, D.C. (30 April 2007), at www.state.gov/j/ct/rls/crt/2006/82736.htm.
} 
that because North Korea had not returned the abductees to Japan it was still a terrorist state and for that reason it should remain on the U.S. list of states sponsoring terrorism. Having been repeatedly reminded about the atrocities of the unresolved abduction issue, the Japanese public appeared to see Japan's relationship with the United States as having suffered because of the Bush administration's plan to remove North Korea from the U.S. list of states sponsoring terrorism. A survey conducted by the Japanese Cabinet Office in October 2007 indicated that the percentage of respondents who viewed the U.S.-Japan relationship in poor shape had increased from 12 percent in 2006 to 20 percent in 2007. ${ }^{36}$ Although President Bush and his administration tried to pacify Tokyo, declaring from time to time that the United States would not forget the abduction issue, this was hardly what was shaping up. The Bush administration was fully prepared to forgo the abduction issue and attendant Japanese concerns if this would help lead to the denuclearization of the DPRK.

This about-face on the part of the Bush administration should not be minimized, as it has often been. A former official in the Bush administration's National Security Council paints the picture that the president was an unyielding advocate of human rights in North Korea where violations are frequently said to be rampant and that his concern with this serious problem was virtually tantamount to that of the DPRK nuclear issue. ${ }^{37}$ However, this is hardly the track taken by the Bush administration. Notwithstanding the repeated contention from Tokyo, incontrovertibly Washington's staunchest Asian ally, that the kidnappings were terrorist acts, thus surely qualifying as major human rights' violations, the Bush administration officially removed North Korea from the State Department's list of countries sponsoring terrorism in October 2008. ${ }^{38}$ The Bush administration delisted North Korea, much to the chagrin of Japanese officials who received very little notice beforehand from Washington that this was about to take place.

Besides ongoing Japanese efforts to forestall the delisting of North Korea as a terrorist state, Tokyo and Pyongyang, in somewhat of a surprise move, announced that they would have bilateral talks in June 2008 in Beijing, their first discussions in many months. Still another bilateral meeting took place in Shenyang, China in August 2008. From the beginning, Tokyo decided to press Pyongyang on the abduction issue during the talks. Although in the past North Korea had consistently held that the abduction issue had already been resolved, that it had held "several investigations" of the kidnappings and that it is impossible to meet Japan's demand, which is "that the DPRK should revive the dead and return them,"39 Pyongyang nonetheless told Tokyo that it would begin a reinvestigation. Tokyo reciprocated saying that it would remove some of the sanctions it had imposed on North Korea because of its missile and nuclear testing in 2006, a carrot that AFVKN was wary of and that the nationalists did not accept.

That these bilateral discussions occurred during June and August of 2008 does make some political sense, especially from Pyongyang's perspective. First, because the moderate

\footnotetext{
36 "Record 20\% of Japanese Say U.S.-Japan Relations not Good", Asahi Shimbun, 3 December 2007.

${ }^{37}$ Victor Cha (2012(: The Impossible State: North Korea, Past and Future, New York, Harper Collins, pp. 203211.

${ }^{38}$ U.S. Department of State, "Briefing on North Korea with Special Envoy for the Six-party Talks Ambassador Sung Kim, Assistant Secretary of State for Public Affairs Sean McCormack, Assistant Secretary of State for Verification, Compliance, and Implementation Paula Sutter, and Acting Assistant Secretary of State for International Security and Nonproliferation Patricia McNerney", Washington, D.C. (11 October 2008), at http://2001-2009.state.gov/r/pa/prs/ps/2008/oct/110926.htm.

${ }^{39}$ Interview with Song Il Ho, Chief Negotiator of DPRK-Japan Talks: "Pyongyang will not Yield an Inch in Demanding Japan's Liquidation of the Past”, The People's Korea, 10 March 2006.
} 
Yasuo Fukuda was at the time prime minister of Japan, Pyongyang was considerably more inclined to meet with Tokyo, to discuss the abduction issue and even agree to a reinvestigation of the kidnappings than it would have had the nationalist Shinzō Abe still been in office. Second, since the DPRK had not yet been removed from the U.S. list of states sponsoring, something Pyongyang very much wanted, meeting with Tokyo could only help North Korea score some political points with at least some officials in the Bush administration.

When Fukuda unexpectedly announced his resignation in early September 2008, the political equation suddenly changed for Pyongyang, particularly since there was a strong possibly that the former foreign minister and nationalist Tarō Asō would become Japan's next prime minister. Pyongyang maintained that when Prime Minister Fukuda quit it immediately notified Tokyo that its position with respect to the bilateral agreement reached in August in Shenyang, China was "invariable." However, Pyongyang also told Tokyo at this time that it "wanted to wait to see the attitude of the new prime minister." Pyongyang notified Japan in September explaining that it would "refrain from" conducting an investigation of the abduction issue until it could evaluate the response of the new prime minister to the August agreement. ${ }^{41}$

Now no longer concerned about losing political points with Washington, Pyongyang hastily reasoned that with Asō as prime minister, Tokyo would be very unlikely to remove some of the sanctions it had imposed on the DPRK as it said it would in August in exchange for the DPRK's willingness to reinvestigate the abduction issue. Just a few days after Asō assumption to the prime minister's position in late September 2008, his administration announced that the sanctions Japan had imposed on the DPRK would be extended for another six months. Pyongyang concluded that "by extending the sanctions the Asō government was following the previous Abe government's hostile policy" toward the DPRK. ${ }^{42}$

Last held in December 2008, the six-party talks then ended with Washington and Pyongyang unable to reach a protocol agreement on verification. This left Tokyo out in the cold with respect to making progress on the abduction issue. With no six-party talks, Tokyo had lost a major access point with which could corner Pyongyang on the abduction issue. Moreover, because Pyongyang viewed the then nationalist-led Japanese government as hostile to the DPRK, it was not about to engage in any meaningful bilateral discussions with Tokyo.

\section{Another U.S. Administration, Still Another Commitment on the Abduction Issue}

It did not take very long for the Obama administration to change the United States' position on the abduction issue. In office less than one month, Secretary of State Hillary Clinton gave a speech at the Asia Society in New York City in which she resurrected America's commitment to the abduction issue - something that had been transmuted into just a rhetorical matter by the Bush administration. During her speech Clinton stated: "I will assure our allies in Japan that we have not forgotten the families of Japanese citizens abducted to North Korea. And I will meet with some of those families in Tokyo next week." ${ }^{, 3}$ She did just that.

\footnotetext{
${ }^{40}$ Author meeting with an official from the DPRK Ministry of Foreign Affairs, Pyongyang, 8 January 2009.

41 "Abduction of Japanese Citizens by North Korea", op. cit.

${ }^{42}$ Author meeting with an official from the DPRK Ministry of Foreign Affairs, Pyongyang, 8 January 2009.

${ }^{43}$ U.S. Department of State, Hillary Rodham Clinton: "U.S.-Asia Relations: Indispensable to Our Future," Remarks at the Asia Society", New York (13 February 2009), at accessed at www.state.gov/secretary/rm/2009a/02/117333.htm.
} 
According to one of the AFVKN representatives who met with Clinton when she was in Tokyo, the secretary stated that "she would think seriously about how to treat the [kidnapping] problem" and that she believed that Washington needed to prioritize the abduction issue so that it could be settled. ${ }^{44}$ Clinton also gave an interview to Japan's largest daily newspaper, the Yomiuri Shimbun. During this interview, which took place after she met with members of the abductees' families, Clinton stated the following:

Well, I was very touched by their stories. It's one thing to read about pain that families have been suffering because of the abduction of their loved ones. And it is very personal to sit with a brother who lost a sister and parents who lost a daughter and to see their pictures at the time that they disappeared, and to hear about the daily anguish that the families feel, because they have - they heard no word for years, did not know what happened, and then they learn that their loved ones have been abducted. And it seems so cruel to have done it in the first place, and then not to provide information and let these people come home with, you know, their own families. So I reassured the families that I met with that the abductee issue is part of the Six-Party Talks; it remains a matter of grave concern to the United States. ${ }^{45}$

Apart from the fact that the six-party talks never took place during the Obama administration's first term, Clinton's unequivocal commitment to the Japanese that the abduction issue would be discussed at these multilateral meetings was somewhat of a shaky step. As noted above, that Tokyo had early on wanted to bring up the abduction issue at the six-party talks was met with resistance by most of the other participants, who felt that these multilateral discussions were about denuclearization and not a specific bilateral problem between Japan and the DPRK.

Indeed, in addition to believing that the Obama administration fully supported Japan's efforts to settle the abduction issue, Tokyo appeared to hold out hope that this matter would be resolved together with the North Korean nuclear issue. With President Obama along side of him, in late May 2011 then Prime Minister Naoto Kan stated the following in Deauville, France: "And we have the issue of North Korea and its nuclear development, and how to stop their nuclear development is a challenge. And also we have this issue of abduction by North Korea, and we will continue to pursue its resolution with the assistance of the United States." 46

\section{Wither New Hope}

Because the discussions in August 2008 between Tokyo and Pyongyang failed to resolve any historical problems, relations between Japan and the DPRK remained poor. And with no sixparty talks, Tokyo and Pyongyang had lost a formal channel of communication with which they could possibly restart bilateral talks. When Tarō Asō resigned from his position in September 2009, the series of prime ministers stretching back to 1998 that came from the LDP had ended. More importantly, from the time Yoshiro Mori made his commitment to the abductees' family members in September 2000 that Japan could not normalize relations with North Korea while disregarding the abduction issue, successive prime ministers from the LDP

\footnotetext{
44 “Clinton Meets Abductees' Relatives, Pledges to Help Find Resolution”, The Japan Times Online, 18 February 2009.

${ }^{45}$ U.S. Department of State: "Yomiuri Shimbun Interview: The Importance of U.S.-Japan Relations," 17 February 2009, at www.state.gov/secretary/rm/2009a/02/117620.htm.

46 The White House, Office of the Press Secretary: "Remarks by President Obama and Prime Minister Kan of Japan before Bilateral Meeting in Deauville, France”, 26 May 2011, at accessed at www.whitehouse.gov/thepress-office/2011/05/26/remarks-president-obama-and-prime-minister-kan-japan-bilateral-meeting-d.
} 
had announced their steadfastness to resolve this problem. This same unswerving commitment to the abduction issue was also politically integral to the policies of successive prime ministers from the Democratic Party of Japan (DPJ) who held office from September 2009 until December 2012. Not much of an alternative existed for Japanese prime ministers, particularly after the second half of 2002. Since then, the abduction issue had become so politicized in Japan that no prime minister, or politician with the ambition to further his or her political career, could afford to be remiss of this matter.

Although the DPRK and Japan had not held official discussions since August 2008, Kim Jong Il's death in December 2011 created the prospect, at least for some Japanese, that Tokyo and Pyongyang could begin to take positive steps to resolve the abduction issue. Family members of the abductees were cautiously optimistic. In the wake of Kim Jong Il's death, Shigeru Yokota, Megumi's elderly father, commented that he hoped that the Japanese "government will take steps to resolve the abduction issue as soon as possible." Another family member remarked that he hoped that the Japanese "government grabs this rare chance to take some serious action," adding that perhaps the new North Korean leader, Kim Jong Un, will conclude that the "abductee problem isn't something from my regime, and that will lead to the possibly that the abductees will be freed." However, Japanese Prime Minister Yoshihiko Noda offered nothing new, stating "Japan's fundamental position is for the earliest possible return of abduction victims. We must continue to gather information to see how the current situation may affect this policy."47

Although himself not demonstrating much optimism, Noda did still want the backing of the Obama administration on the abduction issue. During a telephone discussion with President Obama after Kim's death, Prime Minister Noda requested the United States' support in resolving the abduction issue. ${ }^{48}$ Like Koizumi had done when he visited Pyongyang for the second time in May 2004, ${ }^{49}$ Japanese Foreign Minister Koichiro Gemba had a blue ribbon - which had become Japan's national symbol for the rescue of the abductees $^{50}$ - pinned to his jacket when he talked with Secretary of State Clinton in Washington soon after Kim's death. Noting the increased interest in the kidnappings in Japan in the wake of Kim's death, Foreign Minister Gemba stated, "taking into account this new situation, I ask for continuous understanding and support from the United States for resolving the issue." $" 51$

Whatever amount of optimism existed in Japan about resolving the abduction issue quickly faded away. When Pyongyang announced in March 2012 that it would launch the Kwangmyongsong-3, which it described as an earth observational satellite, in April to honor the $100^{\text {th }}$ birth anniversary of its founder and eternal president Kim Il Sung, Washington moved first to suspend and then to cancel the so-called "leap year deal" it had made with Pyongyang in February. The gist of this deal was that Washington had promised food assistance to the DPRK in exchange for Pyongyang's implementation of some trust-building

\footnotetext{
${ }^{47}$ Quoted material from: “Kim Jong Il's Death Awakens Hope to Resolve Japanese Abduction Issue," The Wall Street Journal, 19 December 2001.

48 "Regime Change in Pyongyang/Hopes Rise for End to Abductions Impasse," Yomiuri Shimbun, 23 December 2011.

${ }^{49}$ Funabashi, op. cit., p. 51.

${ }^{50}$ See: "Abductions of Japanese Citizens by North Korea", op. cit., for an explanation of the symbolic meaning of the blue ribbon.

51 U.S. Department of State: "Remarks with Foreign Minister Koichiro Gemba after Their Meeting", Washington, D.C. (December 2011), at www.state.gov/secretary/rm/2011/12/179127.htm.
} 
measures, both of which created the prospect for the resumption of the six-party talks and perhaps the North's denuclearization.

Washington, Tokyo and Seoul insisted that the Kwangmyongsong-3 was really a disguise for a long-range missile test. Washington and its regional allies, including Japan, maintained that the April launch violated previous UN Security Council resolutions that prohibited the DPRK from deploying any type of ballistic missile technology. ${ }^{52}$ Although not a member of the Security Council, Tokyo wanted it to pass another resolution that would impose additional sanctions on the DPRK. ${ }^{53}$ Because Beijing preferred to exercise some restraint at this time, instead what resulted in just a few days after the launch was a Presidential Statement that strongly condemned the DPRK. ${ }^{54}$ Thus, the collapse of the deal reached in February between Washington and Pyongyang put Tokyo in dire straits, since increased U.S.-DPRK tensions and no near-term prospects for the resumption of the six-party talks translated into no immediate chance for Tokyo to press Pyongyang on the abduction issue.

In May 2012, Glyn Davies, who had only few months earlier taken over the position of U.S. Special Representative for North Korea Policy, was in Tokyo to meet with Jin Matsubara, then Japan's Minister for the Abduction Issue. Davies, who had already met with Megumi Yokota's parents and other victims' family members, remarked to Matsubara before their meeting that every chance that it has the United States presses Pyongyang on the abduction issue. ${ }^{55}$ Davies also again made clear the Obama administration's commitment to the Japanese abduction issue. Said Davies, it is important that Pyongyang recognize "that there will be no ultimate resolution of the differences between North Korea and the United States and the Six Parties unless they resolve this issue - and in particular, unless they keep their promise, their undertaking that they made back in August of 2008 to reinvestigate the cases of abductees." 56

Though not revealed until more than a year and a half later, Pyongyang had proposed in May 2010 to reinvestigate the abduction issue if, in return, Tokyo would remove some of the sanctions - one in particular was the resumption of charter flights from Japan to North Korea - it had imposed on the DPRK. This proposal was made when the DPJ's Yukio Hatoyama was prime minister. Pyongyang supposedly stated that it could establish a committee to reinvestigate the abduction issue "at any time." To convince the Japanese public that the findings were legitimate, Tokyo wanted some Japanese to be members of the committee. However, the reinvestigation matter abruptly ended after Hatoyama resigned and the DPJ's Naoto Kan became prime minister in June 2010, since Pyongyang believed that the new Japanese leader would not work in a friendly manner with the DPRK. ${ }^{57}$

\footnotetext{
52 DiFilippo, Anthony: "Time for North Korea Peace Treaty", The Diplomat, 11 April 2012, at http://thediplomat.com/2012/04/11/time-for-north-korea-peace-treaty/2/.

53 "Govt to Seek UNSC Resolution/Plans to Work with U.S., S. Korea in Condemning N. Korea Launch", Daily Yomiuri Online, 14 April 2012.

${ }^{54}$ United Nations Security Council: "Statement by the President of the Security Council”, New York (16 April 2012), at www.un.org/ga/search/view doc.asp?symbol=S/PRST/2012/13. The Presidential Statement read in part: "The Security Council underscores that this satellite launch, as well as any launch that uses ballistic missile technology, even if characterized as a satellite launch or space launch vehicle, is a serious violation of Security Council resolutions 1718 (2006) and 1874 (2009)".

${ }^{55}$ Notably, there were only a small number of bilateral meetings between Washington and Pyongyang during the Obama administration's first term in office.

${ }^{56}$ U.S. Department of State: "Remarks with Japanese Minister for the Abduction Issue Jin Matsubara Prior to Their Meeting”, Tokyo (25 May 2012), at www.state.gov/p/eap/rls/rm/2012/05/190917.htm.

57 "North Offered to Launch Abduction Probe in 2010", The Japan Times Online, 5 December 2011.
} 


\section{Recent and Other Developments}

The horridness associated with the abduction by DPRK agents of Megumi Yokota in 1977 when she was a young teenager eventually led to her parents, Mr. Shigeru Yokota and Mrs. Sakie Yokota, becoming well-known in Japan and to some extent around the world. The Yokotas became outspoken about the abduction issue, often critical of the Japanese government's failure to do more to press North Korea to account for the abductees and to return them to Japan.

In April 2006, Mrs. Yokota and Megumi's brother visited President Bush at the White House. After talking with Bush, he remarked that he "just had one of the most moving meetings since I've been the President here in the Oval Office." 58

Reflecting the extent to which the abduction issue had become politicized in Japan, in March 2008, the Japanese government's Headquarters for the Abduction Issue published the manga (cartoon - a very popular reading format for all ages in Japan) book entitled Megumi authored and edited by Mr. and Mrs. Yokota. ${ }^{59}$

The Yokotas' political position corresponded with that of the nationalists, who strongly supported taking a hard-line position toward the DPRK. After Kim Jong Il admitted to the DPRK's culpability for the kidnappings in 2002, nationalist heavyweights, such as Shinzō Abe, pushed hard with the help of the media to get the Japanese abduction issue to the top of Japan's national security list. A former official in the Bush administration's National Security Council recounts the following pertaining to when Koizumi, who was accompanied by Abe, then the deputy chief cabinet secretary, visited Pyongyang in September 2002 for his one-day summit with Kim Jong Il. Responding to former Assistant Secretary of State for East Asian and Pacific Affairs Christopher Hill's prodding that the DPRK resolve the abduction issue, Kim Kye-gwan, Pyongyang's chief negotiator in the six-party talks, angrily remarked during a luncheon in New York City: "It's the Japanese that keep raising it. We accounted for all the cases, living and dead. Abe knows that. He was there standing next to Prime Minister Koizumi in 2002 when we agreed. He was nodding in agreement, too. And now he's raising the issue for his political gain. We can never work with him [Abe, who was then serving his first stint as prime minister]."60

\subsection{The Yokotas Change Their Minds}

The Yokotas support of the hard-line, sanctions-based approach toward North Korea was apparent before Abe became prime minister in September 2006 and for years after he left office twelve months later. In their book, Megumi, Shigeru Yokota writes: "Economic sanctions are not an end but a means of resolving this issue, in that they will compel North Korea both to admit it made a mistake in reporting the victims as dead and to understand that resolving the abduction issue is to its own benefit." 61 However, the Yokotas experienced somewhat of a political epiphany in the spring of 2012. At this time, Mr. Shigeru Yokota publicly separated himself from the position consistently held by the nationalists and by NARKN, which has been to strengthen sanctions against the DPRK. Mr. Yokota suddenly

\footnotetext{
${ }^{58}$ The White House: "President Meets with North Korean Defectors and Family Members of Japanese Abducted by North Korea", Washington, DC. (28 April 2006), at http://georgewbush-whitehouse.archives.gov/news/releases/2006/04/20060428-1.html.

${ }^{59}$ Yokota, Shigeru and Yokota, Sakie (2008): Megumi, Tokyo, Headquarters for the Abduction Issue.

${ }^{60}$ Quoted in Cha, op. cit., pp. 370-371.

${ }^{61}$ Yokota and Yokota, op. cit., Afterword 1 (in ed. 2005).
} 
decided that it was wrong to press for beefing up sanctions against North Korea. The Yokotas' new position has become that the passing of Kim Jong Il and the transfer of power to his youngest son Kim Jong Un has created the opportunity to work with Pyongyang to resolve the abduction issue, which they still feel should precede normalized relations between Japan and North Korea.

The Asahi Shimbun, one of Japan's largest newspapers, reported in April 2012 that Shigeru Yokota stated: "Strengthening sanctions could be taken as a sign that Japan is not interested in negotiating." In contrast to the hard-line position endorsed by Japanese hawks, Mrs. Sakie Yokota commented: "I hope Prime Minister Noda will send a message directly to Kim Jong Un ... that they can jointly build peace."62 In June 2012, the Yokotas repeated their views in an interview with the Japanese language publication Weekly Friday. In this interview, the Yokotas said that the Japanese government should establish an environment that facilitates negotiation with Pyongyang and not concentrate solely on sanctions so that the abduction issue should be resolved. ${ }^{63}$

However, the Yokotas apparently do not see eye to eye on everything concerning how to deal with the abduction issue. According to the secretary general of AFVKN, while Shigeru wants bilateral talks between Tokyo and Pyongyang and the removal of sanctions, Mrs. Yokota wants to keep some pressure on North Korea. ${ }^{64}$ A COMJAN (Investigation Commission on Missing Japanese Probably Related to North Korea) official has similarly stated that there is "some difference" between the Yokotas with respect to how to deal with Pyongyang. According to this official, while Mr. Yokota wants the Japanese government to remove the sanctions it has imposed on North Korea, his wife does not necessarily agree with him. 65

In any case, one explanation for the Yokotas' adoption of more conciliatory positions is that these ageing parents (in their late seventies and early eighties) became frustrated because there had not been any official dialogue between Tokyo and Pyongyang between August 2008 and the summer of 2012. ${ }^{66}$ Another explanation is that the nationalists exploited the Yokotas for their political purposes. Proffered by Chongryon (General Association of Korean Residents in Japan), ${ }^{67}$ this explanation proposes that Japanese hardliners have "politically abused" the Yokotas by using their personal grief about Megumi and their political naiveté to help promote a far-right, hard-line DPRK agenda. But because the Yokotas recently have had a change of heart, they now believe that the hard-line position toward North Korea that the Japanese government has been using for years has not worked. ${ }^{68}$

Whatever the real explanation is for the Yokotas' softened positions, one thing is unambiguous: for them genes trumped Japan's political culture with respect to the abduction issue. Their innate desire to see their daughter before they die meant moving away from the hard-line approach and creating some political distance from the nationalist-promoted position that the Japanese media has helped to popularize.

\footnotetext{
62 "Parents' 'Last Word' to Abducted Daughter Published”, Asahi Shimbun, 21 April 2012.

63 "An Interview with Mr. and Mrs. Yokota", Weekly Friday, 15 June 2012 (in Japanese).

${ }^{64}$ Author interview with the secretary general of AFVKN (Association of the Families of Victims Kidnapped by North Korea), Tokyo, 18 July 2012.

${ }^{65}$ Author interview with representatives of COMJAN, Tokyo, 17 July 2012.

${ }^{66}$ Author interview with senior official in Japan's Ministry of Foreign Affairs, Northeast Asia Division, Tokyo, 20 July 2012.

${ }^{67}$ Established in May 1955 in Tokyo, Chongryon politically identifies with the DPRK. For more information and analysis of Chongryon, see DiFilippo, “US-Japan-North Korea Security Relations...", op. cit., Chapter 5.

${ }^{68}$ Author interview with senior official of Chongryon, International Affairs Bureau, Tokyo, 18 July 2012.
} 
The Yokotas believe that Megumi is still alive in North Korea. This is consistent with the official position of the Japanese government. In 2005 and 2006, the Japanese government officially recognized two additional abductees, bringing the total number of abductees to 17 . However, Tokyo points out that it has not ruled out the possibility that more Japanese people have been kidnapped by North Korea. ${ }^{69}$ The private advocacy organization COMJAN, which has been regularly broadcasting the short-wave radio program Shiokaze (Sea Breeze) to North Korea since October 2005, claims that approximately 100 Japanese citizens were probably kidnapped by the DPRK. ${ }^{70}$ According to Tokyo, since Pyongyang has not provided sufficient evidence that the 12 unaccounted for abductees are dead (5 returned to Japan in 2002, see above), as the North has repeatedly claimed, then the assumption is that they are alive. According to the Japanese government's Headquarters for the Abduction Issue, these 12 abductees "are still in captivity in North Korea, torn from their families and loved ones and living in hope of being rescued soon.",71

In 2006, Kim Young-nam, a South Korean living in North Korea since 1978 stated during a press conference that he was Megumi's husband and the father of their daughter Eungyeong. Kim Young-nam denied reports that he had been abducted by North Korea, where he eventually became a citizen. Kim maintained that he ended up in the DPRK "by accident." According to Kim, at the age of 16 he had fallen asleep in a boat that drifted into the sea and that after he awoke he was rescued by a North Korean ship that took him to Nampo in the DPRK. Kim Young-nam stated that Megumi suffered from depression and committed suicide in April 1994, something that both the Yokotas and Tokyo have never accepted. When a Japanese delegation visited Pyongyang in 2004, Kim Young-nam said that they were given Megumi's ashes, which a subsequent DNA analysis performed in Japan maintained were not hers. However, this DNA analysis was controversial, since the young Japanese analyst had no previous experience working with cremated remains and later admitted that his findings could have been contaminated. Making this matter worse was that Japan's National Research Institute was unable to perform a DNA analysis on what Pyongyang said were Megumi's remains. Kim stated that Tokyo's assertion that the ashes given to Japan were not Megumi's was "humiliating" and "If she is alive, how can I say that she is dead." Significantly, results from DNA testing that had been supported by the Japanese government in 2006 revealed that Kim Young-nam was likely Megumi's husband and the father of her daughter Eun-gyeong. ${ }^{72}$

Tokyo acknowledges the likelihood of this familial relationship. However, Tokyo contends that there is evidence that Megumi was seen in North Korea after it was stated she had died, which initially Kim Young-nam indicated was in March 1993. Subsequent to a media report in Japan that Megumi was later seen alive, i.e., after her reputed death, Kim Young-nam said that he had made an "illusional mistake" and that she had died in April $1994 .{ }^{73}$ Former abductee Kaoru Hasuike, who returned to Japan in October 2002 and who

\footnotetext{
69 "Abductions of Japanese Citizens by North Korea”, op. cit.

70 Author interview with representatives of COMJAN, Tokyo, 17 July 2012; see also COMJAN at http://www.chosa-kai.jp/indexeng.htm.

${ }^{71}$ Government of Japan, Headquarters for the Abduction Issue: "Toward a Solution to the Abduction Issue: Directions Given at the Fourth Meeting of the Headquarters for the Abduction Issue", Tokyo, 29 November 2010.

72 DiFilippo, "US-Japan-North Korea Security Relations...”, op. cit., p. 184; "Kim Young-nam Says His Japanese Wife Killed Herself", The Hankyoreh, 30 June 2006; "Son in NK Denies Abduction" Korea Times, 30 June 2006; "Media Resources, Japan Brief", Foreign Press Center Japan, 13 April 2006, at http://fpcj.jp/old/e/mres/japanbrief/jb_622.html.

${ }_{73}$ Author interview with the director of the Japanese government's Headquarters for the Abduction Issue, Tokyo, 12 July 2012; author interview with the secretary general of AFVKN (Association of the Families of Victims Kidnapped by North Korea), Tokyo, 18 July 2012; “Abductions of Japanese Citizens by North Korea”, op. cit.
} 
testified to the Japanese government that he had seen Megumi Yokota alive in 1994, was responsible for causing Pyongyang to change the date of her death. ${ }^{74}$

Several claims of Megumi being appearing to be alive have cropped up from time to time. In May 2008, the Japanese newspaper Mainichi Shimbun reported that Fuki Chimura, an abductee who was kidnapped along with her future husband in July $1978,{ }^{75}$ had several months before informed government officials that Megumi moved into a house next to hers in June 1994, two months after she was said to have died. ${ }^{76}$ In October 2011, a South Korean politician maintained that a North Korean defector had testified that in 2004 he had overheard a DPRK official in charge of Japanese matters in Pyongyang say that Megumi was still alive. The defector also testified that the North had given Japan "fake remains" of Megumi and that she had too much sensitive information to be allowed to return to Japan. ${ }^{77}$ In early November 2011, a story in the Weekly Chosun, a South Korean publication, stated that a female with the same birth date and same family members' names as Megumi Yokota appeared on a Pyongyang residency list that had been compiled in 2005 by the DPRK's intelligence agency. ${ }^{78}$ Pyongyang was particularly critical of one of the claims that Megumi was still living. In June 2005, the DPRK's Korean Central News Agency stated that a Japanese publication, the Weekly Post, reported that in the summer of 2004 British intelligence had acquired information from military satellite surveillance that eventually proved that Megumi was alive. Maintaining that it was a "baseless story," Pyongyang stated that the Japanese far right was using it in "their foolish attempt to inject fresh energy into the waning smear campaign" associated with the abduction issue. ${ }^{79}$

Besides Megumi Yokota, there have been other claims of Japanese abductees who have been said to be alive after they have been reported dead by Pyongyang. NARKN has recently stated that it has acquired reliable evidence that Shuichi Ichikawa, who was abducted in 1978 and who Pyongyang claims died in the following year, was teaching Japanese to North Korean agents from 1982 until 1996. ${ }^{80}$ Although Pyongyang has claimed that Ichikawa died of a heart attack while he was swimming, the Japanese government says that he was not known to have been able to do this when he was living in Japan. ${ }^{81}$ In November 2012, the leader of a South Korean family organization for abduction victims maintained that he had acquired information from knowledgeable sources inside the DPRK revealing that the Japanese abductee Kyoko Matsumoto, who disappeared in 1977 at the age of 29, may have been relocated to Pyongyang in November 2011. According to this account, the current North Korean leader Kim Jong Un, who had been in charge of the abductees when his father Kim Jong Il was living, ordered Matsumoto to be moved to Pyongyang to improve the monitoring of the abductees. ${ }^{82}$

\footnotetext{
74 "Ex-Abductee Hasuike Determined to Help Settle Abduction Issue”, Mainichi Daily News, 15 October 2012.

${ }^{75}$ Following former Prime Minister Junichiro Koizumi's visit to Pyongyang in September 2002, Fukie Chimura and her husband Yasushi returned to Japan in October 2002.

${ }^{76}$ See Megumi Yokota "Seen Alive” in 1994", The Chosunilbo, 27 May 2008.

77 "South Korean Lawmaker Says Japanese Women Abducted by North in 1977 Alive", Yonhap News Agency, 9 October 2011.

78 "Megumi Yokota Seen Alive in 2005”, Jiji Press, 6 November 2011.

79 “KCNA Blasts Japan's Despicable Political Plot", Korean Central News Agency, 13 June 2005.

80 “Info Contradicts North's 'Dead' Abductee Claim”, The Japan Times Online, 11 August 2012.

81 "Abductions of Japanese Citizens by North Korea", op. cit..

82 "Woman Abducted by North may have been Moved to Pyongyang", The Japan Times Online, 26 November 2012.
} 


\section{Still Politicized with No End in Sight}

The abduction issue has remained thoroughly politicized in Japan today; it is accepted staple of Japanese political culture, making virtually all politicians - and not just at the national level - aware of the necessity to appear sympathetic to this problem. In October 2002, shortly after Kim Jong Il revealed the DPRK's culpability pertaining to the abductions and just before the five abductees returned to Japan, the Tokyo-based organization R-Net was formed; thus the launching of the Blue Ribbon Movement, which has as its objective the return of all of the Japanese kidnapped by North Korea. ${ }^{83}$ Since then myriad blue ribbons have been disturbed throughout Japan. ${ }^{84}$ Not only do many Japanese people have these blue ribbons but they are regularly worn by politicians. What is more, over 8.5 million people in Japan at the beginning of 2012 had signed a petition, which was submitted to the prime minister, designed to encourage the central government to rescue the unaccounted for abductees. ${ }^{85}$

Recent survey data from the Japanese government's Cabinet Office indicates that the abduction issue remains very much on the minds of the vast majority of citizens in Japan and that they are fully cognizant of this problem. Over 96 percent of the respondents in the Cabinet Office's survey conducted in June 2012 indicated that they were aware of the details pertaining to the abduction issue and another 3.6 percent said that were aware but not of the particulars. Only .3 percent of the Japanese respondents said that they had not heard of or did not know about the abduction issue. Demonstrating the power of the Japanese media, nearly all of the respondents ( 99.3 percent) said that they had learned about the abduction issue from watching television and a very large percentage (88.3) indicated that newspapers had provided them with information on the kidnappings. ${ }^{86}$ With such heightened sensitivity to the abduction issue in Japan today, it is very difficult for Japanese public servants to attempt to minimize or marginalize this matter.

This, however, does not mean that demonstrated interest in the abduction issue is necessarily an indication of the actual willingness to take action to resolve this problem. During her interview with Asahi Shimbun in April 2012, Sakie Yokota tells of her dislike of posing frequently for photographs with municipal and prefectural politicians in the different places she visited in her and her husband's ongoing campaign to rescue their daughter. If not ulterior motives, certainly at least self interests lie at the root of the desire to be photographed with the Yokotas. And in the interview with Weekly Friday in June 2012, Mrs. Yokota notes with some frustration the myriad ministers for the abduction issue, stating "it is a pity ministers change easily even if we convey our intention."Appointed by different prime ministers, the many ministers for the abduction issue have conveyed the impression of government concern, but their brief tenures strongly suggest perfunctoriness at the national level. In this same interview Mrs. Yokota speaks of the journalists she and her husband have met with so that they could increase public awareness of the abduction issue. Sounding disillusioned and quite skeptical, Mrs. Yokota stated: "I really don't know who I can believe among those politicians or journalists and what the truth is." That many Japanese politicians, journalists and media personnel have so facilely attached themselves to the abduction issue

\footnotetext{
${ }^{83}$ Relying on R-Net's explanation of what the blue ribbon symbolizes, the Ministry of Foreign Affairs notes the following: "Blue. That is the color of the Sea of Japan that separates Japan, the victim's homeland, and North Korea. The color also represents the blue sky, the only thing that connects the victims and their families."

84 "Blue-ribbon Fever Sweeping Nation", The Daily Yomiuri, 23 December 2002.

85 "Abductions of Japanese Citizens by North Korea", op. cit., p. 2.

${ }^{86}$ See: "What Japan Thinks: The North Korean Abduction Issue", 26 July 2012, at http://whatjapanthinks.com/2012/07/26/the-north-korean-abduction-issue.
} 
captures both the extent to which this unresolved problem remains politicized in Japan and their willingness to use the kidnappings to accomplish their specific objectives.

There has been nothing short of a revolving door with respect to individuals holding the position of Minister of State for the Abduction Issue. Indeed, between September 2009, when the DPJ took control of the Japanese government, and October 2012, eight politicians have held this position. Japanese prime ministers have reshuffled their cabinets to score political points and the Minister of State for the Abduction Issue has not been spared from this exercise. When Prime Minister Yoshihiko Noda first reshuffled his cabinet in January 2012, he appointed the conservative Jin Matsubara ${ }^{87}$ to the position of Minister of State for the Abduction Issue. Attempting to bolster public support for his increasingly unpopular government, Noda's third cabinet reshuffle in early October 2012 pushed Matsubara out; replacing him was

Keishu Tanaka ${ }^{88}$ Claiming health problems, which the Noda government underscored, Tanaka resigned at the end of October. However, the political calls for Tanaka to be replaced were widespread after a story appeared in the weekly magazine Shukan Shincho that indicated that in the past he had connections to the Japanese mob (Yakuza) and had received illegal political donations from a company run by a Taiwanese individual residing in Japan. Noda immediately tapped Chief Cabinet Secretary Osamu Fujimura to hold simultaneously the position of State Minister for the Abduction Issue. Counting the previous administrations run by the LDP before the DPJ came to power in 2009, Fujimura became the sixth chief cabinet secretary to hold at the same time the position of State Minister for the Abduction Issue. ${ }^{89}$

Just prior to Tanaka's resignation a top member of AFVKN stated: "It'll be a farce if he's going to quit without doing anything." Although in office only three weeks, Tanaka, who had no experience whatsoever relating to the kidnappings before becoming Minister of State for the Abduction Issue, was apparently going to learn about this matter while on the job. Tanaka upset members of the victims' families by calling them "bereaved families," thus implying that the abductees were dead - something significantly more than a faux pas in Japan. Disillusioned by the very likely departure of Tanaka and the general failure of the Japanese government to resolve the abduction issue, the Yokotas stated: "We have no idea what to believe anymore." 90

Though there had been no real substantive progress in resolving the abduction issue since former Prime Minister Koizumi visited Pyongyang in May 2004, the Noda government, facing a likely defeat in the next election and the prospect of the return of the LDP to power, contacted Pyongyang sometime near March 2012. The Noda government believed that with Kim Jong Un holding power, perhaps it could be easier than in the past to make progress on the abduction issue. Beginning in late June until the end of August, Tokyo and Pyongyang

\footnotetext{
${ }^{87}$ Ignoring the request by Prime Minister Noda, Matusbara and Yuichiro Hata, another cabinet member, visited the Yasukuni Shrine. The Yasukuni Shrine in Tokyo memorializes Japan's military deceased, including a number of war criminals, and is seen by several Asian countries, including China and both North and South Korea, as a symbol of Japanese imperialism. See: "2 Japan Ministers, in Controversial Move, Visit Yasukuni Shrine", Xinhua, 15 August 2012.

88 "Noda Shakes up Cabinet Third Time", The Japan Times Online, 2 October 2012.

89 "Besieged Tanaka Exits over "Health Reasons",, The Japan Times Online, 24 October 2012; "Scandal-hit Tanaka Resigns/ Justice Minister Steps Down over Donations, Gangster Ties”, Daily Yomiuri Online, 24 October 2012; “Taki Back in Office to Replace Tanaka as Justice Minister”, Jiji Press, 25 October 2012.

90 "North Korean Abductee Families Call Justice Minister's Possible Resignation a 'Farce'”, The Mainichi, 20 October 2012.
} 
held secret and unofficial meetings in Beijing with a little discussion given to the abduction issue. ${ }^{91}$ Soon after these secret bilateral talks, Tokyo and Pyongyang held official discussions.

As we will see below, these official bilateral discussions were short-lived and they ended very abruptly. But during the time when these discussions took place, the Noda government apparently had asked Pyongyang sometime around November 2012 to let the Yokotas travel to DPRK to see their granddaughter Eun-gyeong. The Japanese government denied that any such talks had taken place and the Yokotas said that they had not received any information about a possible trip to Pyongyang. ${ }^{92}$ Still, ratcheting up government action with respect to the abduction issue and specifically attempting to arrange for the ageing Yokotas to visit Pyongyang to visit their granddaughter could only be viewed as an achievement for Noda and the DPJ.

\section{A Ray of Hope - Quickly Dashed}

In early August 2012, thus at the same time when Tokyo and Pyongyang were believed to have been having secret, off-the record discussions, officials from the Japanese and North Korean Red Cross organizations had a two-day meeting in Beijing, which had been called for by Japan, the first between them in a decade. The meeting of Red Cross officials was specifically intended to deal with the Japanese civilian and military personnel who died in North Korea at the end of World War II, with the goal of having their remains (still, some 21,600 individuals) sent back to Japan. A top official of the Japanese Red Cross commented: "Overall, I think the meeting was a success." There was, however, no discussion about the abduction issue during the meeting. ${ }^{93}$

About two weeks before the meeting of the Red Cross officials, Pyongyang indicated its annoyance with Jin Matsubara, then Minister of State for the Abduction Issue, who had been repeatedly demanding the return of the abductees before their family members die. Pyongyang labeled Matsubara's statements as "politically-motivated fraud," since the intention was "to win popularity by portraying the dead persons as alive." 94 Soon after the meeting of Red Cross officials, Pyongyang again directed vitriol at Matsubara and at Chief Cabinet Secretary Fujimura. Pyongyang maintained that these officials were not genuine with respect to settling the remains issue, since they wanted to include a discussion of the abductions in the meeting of the Red Cross officials. Said Pyongyang, these Japanese officials wanted to politicize the remains issue, which was a humanitarian matter. ${ }^{95}$

Still, the meeting of the Red Cross officials bore political fruit, since Tokyo and Pyongyang agreed to hold official government talks in Beijing in late August 2012, the first since discussions were held in Shenyang, China in August 2008. Chief Cabinet Secretary Fujimura made clear that Tokyo would press Pyongyang to include the abduction issue in the

\footnotetext{
91 "Govt to Assess N. Korea's Stance on Abductions", The Daily Yomiuri, 16 August 2012; "Japan, North Met in Secret for Months before Beijing Talks", The Japan Times Online, 7 September 2012.

92 "Yokota Visit to Pyongyang in Works?", The Japan Times Online, 16 November 2012; "Abduction Talks Give Families Hope $/ 1^{\text {st }}$ Meeting with N. Korea Since '08 held 35 Years after Yokota Vanished", The Daily Yomiuri, 16 November 2012.

93 “Japan, N. Korea Red Cross to Hold $1^{\text {st }}$ Talks in 10 yrs in Beijing”, Kyodo News International, 9 August 2012; "North Korean Red Cross Pledges to Work to Repatriate Remains of Japanese Wartime Era Dead", The Japan Times Online, 11 August 2012.

94 “KCNA Commentary Rebukes Japan's Rhetoric over ‘Abduction Issue'”, Korean Central News Agency, 25 July 2012.

95 "KCNA Commentary Denounces Japan's Intention to Politicize Humanitarian Issue”, Korean Central News Agency, 16 August 2012.
} 
upcoming government talks. ${ }^{96}$ At the same time, Washington appeared to be sending a signal to the Noda administration not to lose sight of the importance of the six-party framework, which was the disablement of the DPRK's nuclear weapons and programs. Asked about the then pending talks between Tokyo and Pyongyang, a U.S. State Department spokesperson stated that the Obama administration does not oppose discussions between Tokyo and Pyongyang but "we assume that it will - Japan will - that its position that we see in the SixParty Talks will be the same.",97

Tokyo and Pyongyang had three days of official mid-level talks in Beijing at the end of August 2012. These working-level talks focused on the "remains issue," which had been requested by the DPRK during the discussions between Japanese and North Korean Red Cross organizations earlier in the month. These initial bilateral talks seemed to improve Tokyo's and Pyongyang's awareness of each others' concerns. The talks concluded with an agreement to have additional discussions very soon between higher-lever foreign ministry officials from Japan and the DPRK. Although the initial intergovernmental talks did not include any discussion of the abduction issue, Chief Cabinet Secretary Fujimura insisted that the kidnappings would be addressed at any future meeting. ${ }^{98}$ However, a DPRK official involved in these initial working-level discussions pointed out in Beijing before returning home that agenda items in future talks "will be arranged through diplomatic channels." 99

Within just a few days after the conclusion of the working-level talks, Pyongyang presented its position. A spokesman for the DPRK Foreign Ministry remarked that contrary to what Japanese political and media sources are saying, which is that Pyongyang had agreed to include the abduction matter in future bilateral talks and that the North anticipates that it will reap economic benefits from Japan by dealing with the remains issue, "this is a sheer lie." Similar to what it had previously said, Pyongyang charged that the remains issue is a humanitarian problem and that Tokyo is using it for "its sordid political purpose," which will undermine future bilateral discussions. ${ }^{100}$ In mid September, Pyongyang, exhibited a discernibly more acrimonious position, stressing that Japan's strong adherence to the United States' hostile DPRK policy, which has caused it to clamor about the nuclear, missile and abduction issues, contravenes the 2002 Pyongyang Declaration. Pyongyang maintained that Tokyo has continued to "concoct fresh information" on the abduction issue, even though it has already been resolved. It charged that Japan has "set up government organizations and conspiratorial bodies handling the 'abduction issue' in various places, using them as a lever for winning the popularity of conservative politicians." Pyongyang advised that if Japan was truly interested in rapprochement with the DPRK then it must abandoned it hostile policy and execute the Pyongyang Declaration. ${ }^{101}$ In mid October, Kim Yong Nam, the president of the DPRK's Presidium of the Supreme People's Assembly and the second-highest ranking North

\footnotetext{
96 "Japan and North Korea to Hold First Government Talks in Four Years", The New York Times, 14 August 2012.

${ }^{97}$ U.S. State Department, Daily Press Briefing, Washington, August 14, 2012.

98 "Japanese and North Korean Officials Hold First Talks in Four Years", The New York Times, 29 August 2012; "Japan and North Korea Agree to New Talks", The New York Times, 31 August 2012; "North Korea Talks to Include Abductions, But Discussion Likely to be Drawn Out", Asahi Shimbun, 1 September 2012.

99 "N. Korean Official Mum on Response to Japan Call to Discuss Abductions", The Mainichi, 1 September 2012.

100 "Foreign Ministry Spokesman Clarifies the DPRK's Stand on DPRK-Japan Inter-governmental Talks", Korean Central News Agency, 5 September 2012.

101 "DPRK-Japan Relations Hinge on Japan's Attitude: KCNA Commentary", Korean Central News Agency, 17 September 2012.
} 
Korean official, stated: "Before talking about the abduction issue, Japan must reflect on criminal acts it committed against Korean People." 102

After some delay by Pyongyang, in mid November 2012 higher-level talks took place for two days between foreign ministry officials from Japan and the DPRK in Ulan Bator, Mongolia. Leading the Japanese delegation was Shinsuke Sugiyama, the director general of the Ministry of Foreign Affairs' Asian and Oceanian Affairs Bureau; the DPRK's top delegate was Song Il Ho, its official responsible for normalizing relations with Japan. Although Japanese and DPRK officials involved in these talks described them as "content-rich" discussions dealing with "wide-ranging issues," the abduction issue was not an agenda item. However, this was not because Sugiyama did not request that the abduction issue be placed on the agenda. At the conclusion of these talks, Tokyo said it had made "minimum progress" on the abduction issue - perhaps because Japan and the DPRK had agreed to continue with discussions on this matter. Tokyo had not been too optimistic about making much progress during these talks, since it was well aware that Pyongyang saw the impending national elections in Japan and the likely return of the LDP to power as a being potentially problematic. $^{103}$

Coincidently, the first day of the senior-level bilateral talks (November 15, 2012) in Ulan Bator was the $35^{\text {th }}$ anniversary of the abduction of Megumi Yokota in 1977. This created a sense of tepid optimism for the abductees' family members, who could not erase from their memories the failures of the past. "I am devoting body and soul to activities to rescue my daughter, dreaming of her joyful return someday," remarked Mrs. Yokota, who also said: "But the [anniversary] day has come again - the day I hate to remember. I want the government to seriously work on the issue this time." Mr. Yokota commented: "Every year, I'm saddened to see no progress." I want the Japanese government to resolve the issue as soon as possible." Another family member stated: "The abduction issue will not be resolved unless the two governments communicate. We have no time to waste. We want Kaoru [Matsuki] and the others back as soon as possible." 104

Talk about future discussions on the abduction issue agreed to by Tokyo and Pyongyang at the November meetings soon became meaningless. By the end of November, U.S. intelligence and satellite surveillance pointed to heightened activity, similar to that which took place before the North's failed rocket launch in April 2012, at the DPRK's Sohae Space Center in Dongchang-ri, which is located in North Phyongan Province in the western part of the country. ${ }^{105}$ The suspense ended on the first day of December when Pyongyang announced that it would be launching "another working satellite," the Kwangmyöngsóng-3-2, using the Unha- 3 rocket sometime between the $10^{\text {th }}$ and the $22^{\text {nd }}$ of the month.

Tokyo responded immediately. On the same day as Pyongyang's announcement, Prime Minister Noda indicated that Japan would suspend senior-level talks with the DPRK that were to take place on the $5^{\text {th }}$ and $6^{\text {th }}$ of December in Beijing. Japan's Minister of Defense Satoshi

\footnotetext{
102 "Pyongyang: Settle Past Before Talking of Abductions", The Japan Times Online, 14 October 2012.

103 "Talks with N. Korea to Resume Next Week", Daily Yomiuri Online, 10 November 2012; "Japan Calls for Abductions to be on Agenda for Talks with N. Korea", The Mainichi, 16 November 2012; "North Korea Agrees to Continue Talks on Abductees", The Japan Times Online, 18 November 2012.

104 "Aging Parents of Abductee Megumi Yokota in Race Against Time", Kyodo News International, 13 November 2012; “Abduction Talks Give Families Hope $/{ }^{\text {st }}$ Meeting with N. Korea Since '08 held 35 Years after Yokota Vanished”, Daily Yomiuri Online, 16 November 2012.

105 "North Korea May Be Planning Rocket Test, Satellite Operator Says", The New York Times, 27 November 2012.
} 
Morimoto ordered the country's military to ready its missile defense system to intercept the DPRK rocket, should any of it infringe on Japanese territory. Then not likely to be in power too much longer, the Noda government also pointed out that, although Japan did not impose new sanctions on the DPRK after its failed launch in April 2012, should Pyongyang make good on its announcement, this time Tokyo would consider doing it. ${ }^{106}$ Japanese Maritime forces quickly responded to Morimoto's order. Japan's Patriot Advanced Capability-3 (PAC3) ballistic missile interceptors were transported to Okinawa where they would be ready to deal with any parts of the DPRK rocket that entered in Japanese territory. Washington and Seoul also began to take steps to deal with the North's expected launch, authorizing spy satellites and aircraft to keep a close eye on the DPRK's Sohae Space Center at Dongchangri. ${ }^{107}$ All of this heightened military preparedness by Washington, Tokyo and Seoul was reminiscent of the unsuccessful launch that took place in April 2012.

Setting the political tone for its Japanese and South Korean allies, Washington said: “A North Korean 'satellite' launch would be a highly provocative act that threatens peace and security in the region. Any North Korean launch using ballistic missile technology is in direct violation of UN Security Council Resolutions (UNSCRs) 1718 and 1874." ${ }^{\text {"108 }}$ Washington, Tokyo and Seoul also maintained, like they did with the rocket launch in April 2012, that notwithstanding Pyongyang's claim of Kwangmyŏngsŏng-3-2 being a satellite, it was nothing less than a disguised attempt to test a long-range missile. China, the DPRK's chief ally, had a more temperate response to Pyongyang's announcement. The Chinese Ministry of Foreign Affairs stated: "We are concerned about the DPRK's announcement of its plan to launch a satellite and noticed the reactions of other parties. The DPRK is entitled to peaceful use of the outer space which is subject to relevant UN Security Council resolutions." 109

On December $10^{\text {th }}$, the first day of the window in the DPRK's launch, Pyongyang announced that scientists had discovered a technical problem and that it would extend the last day of the launch from the $20^{\text {th }}$ to the $29^{\text {th }}$ of December. ${ }^{110}$ But whether there was indeed a technical problem or Pyongyang was simply attempting to circumvent the heightened surveillance initiated by Washington, Tokyo and Seoul, the DPRK launched the Kwangmyŏngsŏng-3-2 on December $12^{\text {th }}$ and immediately announced that it had succeeded in putting a satellite into orbit. ${ }^{111}$

Again setting the tone for its Japanese and South Korea allies, Washington stated that the DPRK launch, which violated UN Security Council resolutions, was "highly provocative and a threat to regional security" and that "there would be consequences." 112 However, Beijing once again responded in a much more measured way than the U.S. and its allies in

\footnotetext{
106 "Japan to Postpone Bilateral Talks with N. Korea”, The Mainichi, 2 December 2012; "Govt Scuttles N. Korea Talks over Rocket Launch", Daily Yomiuri Online, 3 December 2012; "Bilateral Talks with Pyongyang Postponed over Launch Plans", The Japan Times Online, 3 December 2012.

107 "PAC-3 Interceptors Sent to Okinawa to Intercept N. Korean Rocket", The Mainichi, 3 December 2012 ; "S. Korea, U.S. Step up Military Posture Ahead of N. Korean Rocket Launch", Yonhap News Agency, 3 December 2012.

${ }^{108}$ U.S. Department of State: "North Korean Announcement of Launch" Washington, D.C. (10-22 December 2012), at www.state.gov/r/pa/prs/ps/2012/12/201345.htm.

${ }^{109}$ Ministry of Foreign Affairs of the People's Republic of China: “Foreign Ministry Spokesperson Qin Gang's Remarks on the DPRK's Announcement of Satellite Launch", Beijing (3 December 2012), at www.fmprc.gov.cn/eng/xwfw/s2510/2535/t994638.htm.

110 “DPRK to Extend Satellite Launch Period", Korean Central News Agency, 10 December 2012.

111 "DPRK Succeeds in Satellite Launch", Korean Central News Agency, 12 December 2012.

112 U.S. Department of State: "Daily Press Briefing", Washington, D.C. (12 December 2012), at www.state.gov/r/pa/prs/dpb/2012/12/201930.htm\#NORTHKOREA.
} 
Tokyo and Seoul. Once more noting that the DPRK had the right to use space for peaceful purposes but that existing resolutions from the Security Council prohibited this, Beijing said that it was regrettable that Pyongyang went ahead with the launch. With respect to the likely international response to the DPRK launch, Beijing stated, "China believes that the Security Council's reaction should be prudent, moderate and conducive to maintaining peace and stability of the Korean Peninsula so as to avoid further escalation of situation."113

In the final days of the Noda administration, Tsuneo Nishida, Japan's ambassador to the United Nations stated more than a week after the North Korean launch that the Security Council had not reached an agreement on the matter of how to deal with the DPRK. Nishida noted that Washington, Tokyo and Seoul's position with respect to the North's launch, which is to impose additional sanctions on the DPRK, compared to that of Beijing, which opposes the hard-line approach, "are far too divided" for them to "sustain discussions.", 114

In late December, however, some saw another possible approach that could lead to punishing Pyongyang for the launch earlier in the month. Because South Korea would become a nonpermanent member of the UN Security Council in 2013 for two years, some believed that Seoul could have an impact in pushing this body to take punitive action against Pyongyang for the rocket launch. ${ }^{115}$ At the time this appeared to be closer to wishful thinking than reality, since although Beijing certainly had concerns about the North's December launch, it gave no indication that it was willing to pile additional sanctions from the Security Council on the DPRK.

The DPJ lost badly to the LDP in Japan's December 2012 elections. Since Abe had been elected president of the LDP in September, the party's electoral victory almost assuredly meant that he would once again become prime minister. Not at all pleased with his approach to the DPRK from just a few years earlier, Pyongyang indicated that Abe is on "the extreme right."

Abe lost no time in establishing his new administration's position toward North Korea. Just two days after becoming prime minister, Abe, in a late December meeting with the relatives of the abductees, including the Yokotas, said that the Japanese government could unilaterally impose additional sanctions on the DPRK as a way to persuade Pyongyang to discuss the kidnappings and to make progress on this issue. In the typical exaggerated and rhetorical style used by many politicians, Abe told the family members at the meeting: "I am determined to resolve the issue. I will be making efforts every day to deliver results, not just words." These comments appeared to reignite some optimism among the family members, who undoubtedly recalled Abe's establishment within the government of the Headquarters for the Abduction Issue in October 2006 when he was prime minister and his many ad hominem proclamations from the past about resolving this problem. A member of AFVKN stated: "We are filled with expectations that the government will provide a path [to settling the abduction issue] at an early time next year. I hope the government will seek to resolve the issue regardless of the situation it faces." 116

\footnotetext{
${ }^{113}$ Ministry of Foreign Affairs of the People's Republic of China: "Foreign Ministry Spokesperson Hong Lei's Regular Press Conference on December 12", Beijing (13 December 2012), at www.fmprc.gov.cn/eng/xwfw/s2510/2511/t997918.htm.

114 "No Viable UN Talks on North Seen", The Japan Times Online, 22 December 2012.

115 "S. Korea to Join UN Security Council amid Deadlock over N.K. Rocket", Yonhap New Agency, 29 December 2012.

116 “Abe Vows to Resolve Abductions", The Japan Times Online, 29 December 2012.
} 
Abe's comment about persuading via sanctions North Korea back into negotiations notwithstanding, it was Pyongyang that made the first move to initiate bilateral talks after they had been abruptly ended by the Noda administration because of the North's announcement that it was preparing to launch a satellite. During the second half of December, Pyongyang requested bilateral discussions to begin perhaps in February 2013; however, it specifically stated that the earlier agreement it made with the Noda administration that the abduction issue be taken up at future talks be discarded. Seeming nonplused, a senior official in the Abe administration remarked: "We're not yet able to figure out what Pyongyang means, and it's still likely the North may repeat provocative acts, such as an additional missile test and a nuclear test." 117 How shirking Pyongyang's offer comported with engaging in daily efforts to resolve the abduction issue promised by Abe to the relatives of the abductees is not clear, given that this problem can only be settled diplomatically though bilateral discussions.

\section{Analysis and Prospects}

It remains to be seen just how much different Abe's second run at prime minister will be from his first. But early indications are that he will exhibit even more of the predilections associated with the hawkish, nationalist agenda than before.

Soon after becoming prime minister in December 2012, Abe had plans to visit the Washington to discuss with President Obama the U.S.-Japan security alliance. Abe has made no secret that he wants to whitewash Japan's aggression associated with its imperialist past, as well as strengthen both its military capabilities and security alliance with the United States. Relative to the Noda administration, Abe's government has placed on a fast track consideration for buying the U.S.-made Global Hawk, an advanced unmanned surveillance aircraft, which if purchased - something that South Korea has already done and has angered the North ${ }^{118}$ - will be used for collecting intelligence on China and North Korea. ${ }^{119}$ The Abe administration has intimated that it is considering the revision of the 1995 Kono Statement in which Japan officially apologized for its military's use of juugun ianfu (comfort women) during World War II, ${ }^{120}$ a move that will instantly create animus in some Asian countries, including North and South Korea. The Abe administration plans to raise Japan's military budget, the first time in more than 10 years. ${ }^{121}$ In fact, in early January, the Abe administration revealed its plan to spend an additional ¥180.5 billion (approximately $\$ 2.1$ billion) for fighter planes, missiles and helicopters over and above the anticipated increase in military spending for 2013. ${ }^{122}$ The day after he was elected president of the LDP in September 2101, with the expectation of becoming Japan's next prime minister, Abe maintained, "I have long emphasized the need to exercise the right to collective self-defense in rebuilding the Japan-U.S. alliance." 123 And showing deference to Washington's dominant position in the bilateral alliance, he commented soon after becoming prime minister: "Reviewing the right to collective self-defense is one of Abe administration's central policy aims, and because of that

\footnotetext{
117 "North Asks to Resume Talks in February", The Japan Times Online, 1 January 2013.

118 "Global Hawk Sale to South Korea Helps in Creating Global Surveillance Network", DefenseWorld.net, 8 January 2013, at

www.defenseworld.net/go/defensenews.jsp?id=7979\&h=Global\%20Hawk\%20Sale\%20To\%20South\%20Korea \%20Helps\%20In\%20Creating\%20Global\%20Surveillance\%20Network; "U.S. Reckless Hostile Policy towards DPRK Under Fire", Korean Central News Agency, 7 January 2013.

119 "Govt Eyeing Purchase of U.S. Spy Drones/Global Hawks would Cover China, N. Korea", Daily Yomiuri Online, 1 January 2013.

120 "Japan Hints It May Revise an Apology on Sex Slaves", The New York Times, 27 December 2012.

121 "SDF Spending Targeted to Rise in Fiscal Year 2013”, The Japan Times Online, 7 January 2013.

122 “¥180.5 in Extra Defense Outlays Eyed”, The Japan Times Online, 10 January 2013.

123 “Abe Eyes Lifting Ban on Collective Self-defense”, Asahi Shimbun, 27 September 2012.
} 
I want to discuss it with President Obama." ${ }^{, 124}$ Specifically, what Abe plans to do is to revise the U.S.-Japan Guidelines for Defense Cooperation, which was last updated in the $1997,{ }^{125}$ and to change the Japanese government's interpretation of the constitution to permit collective defense. ${ }^{126}$ Since collective defense - participation in war activities with an ally (the United States) - is currently interpreted as a violation of the Japanese constitution, changing this would be still another step along the path of making Japan a futsu kokka (normal country), i.e., a nation with a strong and constitutionally unfettered military. ${ }^{127}$ Article 9 of Japan's constitution prohibits "the threat or use of force as means of settling international disputes" and the possession of "war potential." Unable to revise Article 9 during his first one-year stint as prime minister, Abe, like other conservative hawks, would like to succeed this time in revising this war-renouncing constitutional clause. Abe, specifically, wants Japan's Self Defense Forces as stipulated in Article 9 changed to a "national defense military." "28 Given Japan's past behavior of military aggression, all of this, which Washington has generally endorsed, has not only disturbed Pyongyang and Beijing ${ }^{129}$ but Seoul as well. ${ }^{130}$

The Obama administration objected to former New Mexico governor Bill Richardson and Google boss Eric Schmidt's trip to North Korea in early January 2013, maintaining that their traveling to the DPRK, which had only the month before launched a rocket in violation of UN Security Council resolutions, would send the wrong signal to Pyongyang. The U.S. State Department's spokesperson made clear that Richardson and Schmidt "are traveling in an unofficial capacity. They are not going to be accompanied by U.S. officials. They are not carrying any messages from us. Frankly, we don't think the timing of this is particularly helpful." "131 Because Washington had not yet succeeded in getting the UN Security Council to agree on the "consequences" it had promised to impose on the DPRK for its December rocket launch, it is certainly plausible that the Abe administration appeared to be perplexed when Pyongyang offered to restart Japan-DPRK talks. Although then unable to get the Security Council to move on Pyongyang because of its rocket launch, Washington, with support from Tokyo and Seoul, was still trying in early 2013. Given the value to the Abe government of both strengthening Japan's military and its security alliance with the United States, responding positively to Pyongyang's offer for new bilateral talks without coordinating its actions with Washington would likely have angered the Obama administration, somewhat similar to the way Richardson and Schmidt's trip did. Thus, the Japanese abduction issue was put on hold. In mid February 2013, immediately after the DPRK conducted its third underground nuclear test (see below), Megumi's mother Sakie Yokota, showing her mistrust

\footnotetext{
124 “Abe: "I'll Discuss Right to Collective Self-defense with Obama”, Asahi Shimbun, 14 January 2013.

125 DiFilippo, "The Challenges of the U.S.-Japan Military Arrangement...", op. cit., esp. pp. 33-36.

126 "Govt Seeking Expansion of SDF Role", Daily Yomiuri Online, 17 January 2013.

${ }^{127}$ DiFilippo, "US-Japan-North Korea Security Relations...", op. cit., Chapter 3; Hughes, Christopher: "Japan's Military Modernisation: A Quit Japan-China Arms Race and Global Power Projection", Asia-Pacific Review, vol. 16, no.1 (2009), pp. 84-99.

128 “Abe Seeks Partners to Pave Way for Constitutional Revision”, International Herald Tribune, 18 December 2012; “Abe Pushes Constitutional Reform, "National Defense Military' in Diet”, The Mainichi, 2 February 2013. For Pyongyang's reaction, see: "Japan's Moves for Militarization, Overseas Expansion Assailed", Korean Central News Agency, 20 February 2013.

129 "Japan Accused of Working Hard to Realize 'Greater East Asia Co-prosperity Sphere", Korean Central News Agency, 15 January 2013; “Abe is Taking Japan Down a Dangerous Path”, China Daily.com, 17 January 2013, at www.chinadaily.com.cn/opinion/2013-01/17/content_16132153.htm.

130 "U.S. Keeps Strategic Hush on Japan's Military Ambitions", Yonhap News Agency, 16 January 2013.

${ }^{131}$ U.S. Department of State: "Daily Press Briefing”, Washington, D.C. (3 January 2013), at www.state.gov/r/pa/prs/dpb/2013/01/202480.htm.
} 
of the Japanese government, remarked "I wonder why Japan did not respond when North Korea suggested resuming government-to-government talks at the end of last year." ${ }^{132}$

In mid January 2013, new Japanese Foreign Minister Fumio Kishida traveled to Washington and met with Secretary of State Clinton, who remarked: "On North Korea we shared our joint commitment to strong action in the UN Security Council" because of its December launch. Kishida too was forthright on this matter: "On North Korea, we confirmed that close collaboration be continued between Japan and the United States, as well as between Japan, United States, and South Korea. Specifically referring to the missile launch last December, we agreed to continue with our close cooperation so that the United Nations Security Council takes effective measures as expeditiously as possible."133 Supported by Tokyo and Seoul, Washington's tenacity finally paid off. In late January, the UN Security Council passed Resolution 2087, which condemned the DPRK for its December launch and imposed sanctions beyond those that had been authorized since 2006 for its missile and nuclear tests. ${ }^{134}$ Rejecting the resolution, which it said Washington initiated and Seoul fabricated, Pyongyang immediately promised to launch more satellites and long-range rockets and conduct another "nuclear test of higher level. ${ }^{135}$

It is worth pointing to the possibility that Japan may not necessarily place a high premium on rapprochement with North Korea and even resolving the abduction issue, despite the ongoing political rhetoric to the contrary. First, it can be plausibly argued that the DPRK and China, which is currently involved in a heated dispute with Tokyo over possession of islands (Senkaku, Japanese and Diaoyu, Chinese) in the East China Sea, have been used by Japanese politicians to push Japan along the path of becoming a futsu kokka. As we will see in more detail below, the abduction issue is primarily a security issue in Japan. Second, some North Korean supporters in Japan maintain that Tokyo claims that all of the abductees are still alive in North Korea today because the Japanese government does not want to provide compensation to the DPRK for its past colonization of Korea, ${ }^{136}$ something that if true could more easily reflect the sentiments of the hawkish and nationalist-inspired Abe government. Rapprochement with the DPRK would cost Japan plenty today and Tokyo is well aware of this. When Japan normalized relations with South Korea in 1965, it provided Seoul with a package amounting to $\$ 800$ million - $\$ 300$ million in grant aid, $\$ 300$ million in credits from Japanese financial institutions and $\$ 200$ in government long-term, low-interest loans. ${ }^{137}$ To get Pyongyang to agree today, any reparations given to North Korea today would need to be considerably higher than the amount provided nearly a half century ago to the South. Add to this Japan's struggling economy and the predisposition of nationalists to minimize past imperial aggression and what plausibly emerges is a Japanese position that gives more lip service than substance to rapprochement and resolving the abduction issue.

Japanese politicians have long politicized the abduction issue, typically crafting it for public consumption as an unresolved humanitarian issue caused by terrorist acts perpetrated

\footnotetext{
132 “Kin Fear N. Korea Nuclear Test Could Push Back Abduction Resolution”, The Mainichi, 13 February 2013.

${ }^{133}$ U.S. Department of State: "Remarks with Foreign Minister Fumio Kishida after Their Meeting", Washington, D.C. (18 January 2013), at www.state.gov/secretary/rm/2013/01/203050.htm.

134 United Nations Security Council: "Resolution 2087", New York (22 January 2013) at www.un.org/ga/search/view_doc.asp?symbol=S/RES/2087\%282013\%29\&referer=http://www.un.org/en/sc/docu ments/resolutions/2013.shtml\&Lang=E.

135 "DPRK NDC [National Defense Commission] Vows to Launch All-out Action to Defend Sovereignty of Country", Korean Central News Agency, 24 January 2013; "S. Korean Authorities Accused of Fabricating UN 'Resolution' with Foreign Forces”, Korean Central News Agency, 25 January 2013.

${ }^{136}$ Author interview with senior official of Chongryon, International Affairs Bureau, Tokyo (18 July 2012).

137 Manyin, op. cit.
} 
by the DPRK. The Abe administration's recent gambit with respect to the politicization of the abduction issue came early in 2013 when it announced that in February it would present a resolution to the UN Human Rights Council requesting the establishment of an expert group to investigate the Japanese kidnappings by the DPRK and some of the North's other human rights violations. Appearing only to demonstrate political bark for Japanese public consumption rather than bite, the Abe administration was well aware that even if the UN Human Rights Council adopted such a resolution, the expert group would have no legal authority to enforce it. ${ }^{138}$

Since 2002, when Kim Jong Il revealed the North's culpability, Japanese politicians have frequently remarked that there can be no normalization of relations between Japan and the DPRK until there is a resolution to the abduction issue. Shinzō Abe helped play a big part in establishing this national criterion. During a policy speech he delivered just three days after becoming prime minister for the first time in September 2006, Abe announced his intention to create the Headquarters for the Abduction Issue and remarked: "There can be no normalization of relations between Japan and North Korea unless the abduction issue is resolved." 139 Thus, a statement still appearing on the website of the Headquarters for the Abduction Issues states: "The abduction of Japanese citizens is a matter of grave concern that affects the national sovereignty of Japan and the lives and safety of the Japanese people. Until this issue is resolved, there can be no normalization of relations with North Korea."140 Moreover, Tokyo has often used Washington as a sounding board for the abduction issue. During Foreign Minister Kishida's visit to Washington in January 2013, he remarked to Secretary of State Clinton how important the abduction is to the Abe administration and requested ongoing support and assistance from the United States. Clinton told Kishida that the United States “would continue to support Japan's efforts to return Japanese citizens who have been abducted by the DPRK." 141

While the abduction issue does represent a humanitarian problem, it is inextricably tied to security in Japan, specifically the DPRK missile and nuclear issues. Washington, as the dominant player in the U.S.-Japan security alliance, has insisted on the nuclear disarmament of the DPRK, as well as an end to its long-range missile testing. Although Japan has shared these objectives, Tokyo has yet to stray too far from Washington's leadership to resolve the abduction issue independent of the missile and nuclear problems. This is because the denuclearization of the DPRK, which Washington orchestrates for Tokyo and for Seoul as well, trumps everything, including the abduction issue when it comes to security in East Asia. From the first meeting of the six-party talks in August 2003, Tokyo has stressed that the resolution of the abduction issue is a prerequisite to normalized Japan-DPRK relations. ${ }^{142}$ But apart from working to bring up the kidnappings at the six-party talks, it is clear that even before the beginning of these multilateral discussions Tokyo tied the resolution of the abduction issue to security matters. Indeed, a relatively recent statement from the Headquarters for the Abduction Issue indisputably makes this connection. The statement reads: "As set down in the Japan-DPRK Pyongyang Declaration [September 2002], we wish to reach a comprehensive resolution of outstanding issues of concern, including the abduction

\footnotetext{
138 "Tokyo to Turn up Heat on North at UN", The Japan Times Online, 4 February 2013.

${ }^{139}$ Prime Minister and His Cabinet: "Policy Speech by Prime Minister Shinzo Abe to the $165^{\text {th }}$ Session of the Diet”, Tokyo (29 September 2006), at www.kantei.go.jp/foreign/abespeech/2006/09/29speech_e.html.

${ }^{140}$ See “Abduction of Japanese Citizens by North Korea...”, op. cit.

${ }^{141}$ U.S. Department of State: "Remarks with Foreign Minister Fumio Kishida after Their Meeting", Washington, D.C. (18 January 2013).

${ }_{142}$ MOFA: "Japan-North Korea Relations", Tokyo (May 2004), at www.mofa.go.jp/region/asiapaci/n_korea/relation.html.
} 
issue and North Korea's nuclear and missile programs, to settle the unfortunate past between us, and to move to normalize diplomatic relations. Toward that end, it is absolutely indispensable to resolve the abduction issue." 143

Insisting that they are still alive in North Korea, a position also taken by Washington, Tokyo has not reasonably answered the question of why Pyongyang would want to keep the abductees today. During the Cold War, Japanese abductees had value to the DPRK's intelligence agencies. Today, they do not. To simply maintain, as does Tokyo and private groups in Japan, that the abductees have information about the DPRK that Pyongyang does not want to reveal to the outside world is somewhat of a political stretch. Would not the abductees and their family members that were permitted to return to Japan have some state secrets as well? Would Pyongyang - or any government for that matter - reveal high-level state secrets to foreign abductees?

Ironically, Tokyo has never articulated a specific detailed explanation of how the abduction issue can be satisfactorily resolved. This suggests that history and ideological disparity have created serious roadblocks to the resolution of the abduction issue. For example, Tokyo has complained that the records the DPRK furnished to Japan about the socalled deaths of the abductees is inconsistent and unconvincing. Presented with the possibility that record-keeping in the DPRK may not be the same as it is in Japan, a senior official in the Japanese Ministry of Foreign Affairs remarked "if it were some other country Japan could accept poor-recording keeping, but not with North Korea. ${ }^{144}$

That the abduction issue remains unresolved is certainly not only Tokyo's fault. Because North Korean agents perpetrated the kidnappings, despite whether or not they received Pyongyang's imprimatur, DPRK officials need to work much harder to resolve the abduction issue. Whether or not it is true that the remaining victims who have not yet been accounted for are dead or never entered the DPRK, as Pyongyang maintains, it is simply not sufficient to state this while insisting that the abduction issue was resolved sometime ago when former Prime Minister Koizumi visited the North.

If Pyongyang has nothing to hide, then it needs to demonstrate to Tokyo and the global community complete openness and willingness to provide all there is to know about the abductees. Tokyo has repeatedly sought a reinvestigation of the abduction issue. It could do no harm for Pyongyang to invite a Japanese team to the DPRK to carry out a thorough investigation of the abduction issue with full cooperation and assistance from the North.

Just a Tokyo has politicized the abduction issue so too has Pyongyang. As we saw above, in June and especially in August 2008, when they finalized their agreement, Japanese and DPRK officials held bilateral talks. Pyongyang agreed to reinvestigate the abduction issue, for which Tokyo promised that it would lift some of the sanctions it had then recently imposed on the DPRK. Recall also that after Fukuda left office at the end of September 2008 and the nationalist Tarō Asō became Japan's new prime minister his administration quickly announced that it would extend for another six months the sanctions that Japan had imposed on the DPRK for its missile and nuclear testing. However, the Aso government did state that

\footnotetext{
${ }^{143}$ Government of Japan, Headquarters for the Abduction Issue: "Toward a Solution to the Abduction Issue: Directions Given at the Fourth Meeting of the Headquarters for the Abduction Issue", (29 November 2010).

${ }^{144}$ Author interview with senior official in Japan's Ministry of Foreign Affairs, Northeast Asia Division, Tokyo, 20 July 2012.
} 
Japan would honor the bilateral agreement and lift some of the sanctions it had imposed on the DPRK as soon as Pyongyang began a reinvestigation of the abduction issue. ${ }^{145}$

Because of the Asō government's decision to extend sanctions, Pyongyang angrily complained that Tokyo had once again linked the abduction issue to the six-party talks. Pyongyang also intimated that Japan's refusal to provide the DPRK the energy assistance, which the joint statement produced by the six-party talks held in February 2007 had stipulated as obligatory for all of the other participants so that the nuclear matter could be resolved, was consistent with Tokyo's undermining of the bilateral agreement reached in August. ${ }^{146}$ Instead of abandoning it, Pyongyang could have moved forward with the reinvestigation of the abduction issue. Had Pyongyang proceeded with the reinvestigation, particularly with sincere enthusiasm, this would have put the Asō government in the position where it either had to lift some of the sanctions Japan had imposed on the DPRK or face the charge of unequivocally reneging on the bilateral agreement reached in August 2008. By reacting hastily to the Asō government's announcement to extend the sanctions regime on the DPRK, Pyongyang effectively jettisoned the reinvestigation of the abduction issue and therefore provided Tokyo with the justification for not lifting some sanctions.

In late 2012, Pyongyang expressed an interest in reinvestigating the abduction issue. However, as we have seen, the DPRK's rocket test in December put a quick end to JapanNorth Korea discussions. And Pyongyang's unwise and requited decision to conduct a third underground nuclear test in February 2013 because it wanted to demonstrate its disapproval of the Washington-led UN Security Council resolution sanctioning it for its December 2013 satellite launch, put the prospect of Japan-North Korea talks in political limbo, certainly for the near term. Prime Minister Abe and President Obama expressed the same view of further sanctioning the DPRK because of its third nuclear test. ${ }^{147}$ That Abe called on the Security Council to respond quickly to the DPRK's third nuclear test and promised to extend Japan's sanctions against North Korea, while urging "it to take concrete action towards comprehensively resolving outstanding issues of concern, including the abductions, nuclear and missile programs," ${ }^{148}$ offers little optimism for resolving the abduction issue anytime soon.

Indeed, the family members of the abductees are certainly cognizant of this. ${ }^{149}$ Expressing concern that the North's third nuclear test would further defer bilateral talks between Tokyo and Pyongyang, Shigeru Yokota, Megumi's father, commented: "I wish the [Japanese] government would conduct negotiations on the abduction issue separately from the issue of the nuclear test." ${ }^{150}$ However, even in the unlikely event that Japan-DPRK talks do take place relatively soon, Tokyo has long tied the abduction issue to the North Korean nuclear and missile problems and both of these can only be resolved by approbation from

\footnotetext{
${ }^{145}$ DiFilippo, “US-Japan-North Korea Security Relations”, op. cit., p.182.

146 "KCNA Slams Japan's Dishonest Stance towards Issue of Fulfillment of Its Commitment”, Korean Central News Agency, 22 October 2008.

147 “Abe, Obama Share Stance on N. Korea/2 Leaders Seek Tough UNSC Resolution”, Daily Yomiuri Online, 15 February 2013.

${ }^{148}$ Prime Minister of Japan and His Cabinet: "Statement by the Prime Minister of Japan (on the Nuclear Test by North Korea)", Tokyo, 12 February 2013, at

www.kantei.go.jp/foreign/96_abe/decisions/2013/0212statement_e.html; For Pyongyang's reaction to Japanese sanctions stemming from the DPRK's launch in December 2013, see: “KCNA Denounces Japan for Tightening Sanctions on Koreans", Korean Central News Agency, 17 February 2013.

149 “Abductees' Kin Angry After N-test”, Daily Yomiuri Online, 13 February 2013; “Kin Fear N. Korea Nuclear Test Could Push Back Abduction Issue Resolution”, The Mainichi, 13 February 2013.

150 “Abductees' Kin Worry N-test May Delay Talks”, Daily Yomiuri Online, 14 February 2013.
} 
Washington. This ultimately makes the settlement of the abduction issue contingent upon the resolution of the nuclear and missile problems. That both Tokyo and Pyongyang have politicized the abduction issue is just part - albeit a big one - of the reason why it remains unresolved. For Pyongyang, the abduction issue pales in comparison to the outstanding historical matters that stem from Japan's colonization of the Korean Peninsula. However, Pyongyang's failure to work to disentangle the abduction issue from Japan's perceived security interests in East Asia have served to exacerbate its politicization.

Considerably less songun-inspired bravado from Pyongyang would help establish an opening for ameliorating the security environment in Northeast Asia and thus plant the political seeds for improving North Korea-Japan relations. Pyongyang's decision to perform a third nuclear test specifically "to express the surging resentment of the army and people of the DPRK at the U.S. brigandish hostile act" (i.e., leading the way in punishing the North for its December satellite launch via UN Security Council Resolution 2087) is not a pragmatic way to conduct foreign policy. ${ }^{151}$ That China, the DPRK's closest ally, has been unwilling to veto UN Security Council resolutions sanctioning the North since 2006 does indicate that Beijing's tolerance of Pyongyang's songun decisions has been running thin. Responding to the DPRK's third nuclear test, Beijing stated: "The Chinese Government is firmly opposed to this act." What is more, after summoning the DPRK's Ambassador in Beijing Ji Jae Ryong, Chinese Foreign minister Yang Jiechi told him that China was "strongly dissatisfied with" and "firmly opposed to" Pyongyang's decisions to conduct its third nuclear test. ${ }^{152}$

Pyongyang has long wanted a permanent peace treaty to end the Korean War. Much more consistent emphasis on the need to establish a peace treaty ${ }^{153}$ and much less willingness to demonstrate songun, particularly by relying on nuclear testing, could dissipate some regional tension and create a foundation for a resolution to outstanding problems, including the abduction issue.

\footnotetext{
151 "Spokesman for DPRK Foreign Ministry Urges U.S. to Choose between Two Options", Korean Central News Agency, 12 February 2013.

${ }^{152}$ Ministry of Foreign Affairs of the People's Republic of China: "Statement of the Ministry of Foreign Affairs of the People's Republic of China", Beijing, 12 February 2013, at

www.fmprc.gov.cn/eng/zxxx/t1013361.shtml013; “China 'Firmly' Opposes DPRK's Nuclear Test; Yang Summons Ambassador”, Xinhua, 12 February 2013.

${ }^{153}$ For the specifics of a "conditional peace treaty" that would fairly address both Washington's and Pyongyang's concerns and that could become a permanent accord, see Anthony DiFilippo, "North Korea's Denuclearization and a Peace Treaty", North Korean Review, vol. 7, no. 1 (Spring 2011), pp. 7-20.
} 